\title{
Eutrophication in shallow coastal bays and lagoons: the role of plants in the coastal filter
}

\author{
Karen J. McGlathery ${ }^{1, *}$, Kristina Sundbäck ${ }^{2}$, Iris C. Anderson ${ }^{3}$ \\ ${ }^{1}$ Department of Environmental Sciences, University of Virginia, 291 McCormick Road, PO Box 400123, Charlottesville, \\ Virginia 22903, USA \\ ${ }^{2}$ Department of Marine Ecology, Marine Botany, Göteborg University, PO Box 461, 40530 Göteborg, Sweden \\ ${ }^{3}$ School of Marine Science, Virginia Institute of Marine Science, College of William and Mary, Gloucester Point, \\ Virginia 23602, USA
}

\begin{abstract}
Nutrient loading to coastal bay ecosystems is of a similar magnitude as that to deeper, river-fed estuaries, yet our understanding of the eutrophication process in these shallow systems lags far behind. In this synthesis, we focus on one type of biotic feedback that influences eutrophication patterns in coastal bays - the important role of primary producers in the 'coastal filter'. We discuss the 2 aspects of plant-mediated nutrient cycling as eutrophication induces a shift in primary producer dominance: (1) the fate of nutrients bound in plant biomass, and (2) the effects of primary producers on biogeochemical processes that influence nutrient retention. We suggest the following generalizations as eutrophication proceeds in coastal bays: (1) Long-term retention of recalcitrant dissolved and particulate organic matter will decline as seagrasses are replaced by algae with less refractory material. (2) Benthic grazers buffer the early effects of nutrient enrichment, but consumption rates will decline as physico-chemical conditions stress consumer populations. (3) Mass transport of plantbound nutrients will increase because attached perennial macrophytes will be replaced by unattached ephemeral algae that move with the water. (4) Denitrification will be an unimportant sink for $\mathrm{N}$ because primary producers typically outcompete bacteria for available N, and partitioning of nitrate reduction will shift to dissimilatory nitrate reduction to ammonium in later stages of eutrophication. In tropical/subtropical systems dominated by carbonate sediments, eutrophication will likely result in a positive feedback where increased sulfate reduction and sulfide accumulation in sediments will decrease $\mathrm{P}$ adsorption to Fe and enhance the release of $\mathrm{P}$ to the overlying water.
\end{abstract}

KEY WORDS: Eutrophication - Coastal bay · Lagoon · Nitrogen · Phosphorus · Seagrass · Macroalgae · Phytoplankton

Resale or republication not permitted without written consent of the publisher

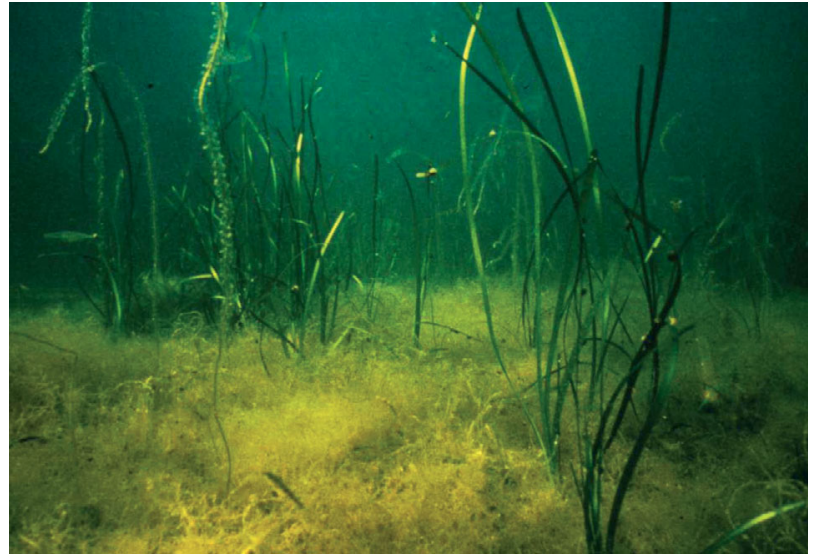

Eutrophication of shallow coastal bays typically causes a shift in dominance from seagrasses and perennial macroalgae to ephemeral, bloom-forming algae.

Photo: Peter Bondo Christensen

\section{INTRODUCTION}

Shallow coastal bays and lagoons are particularly vulnerable to the rapid changes in population and land use occurring in the coastal zone (Sand-Jensen \& Borum 1991, Duarte 1995, Valiela et al. 1997, NRC 2000, Havens et al. 2001, Nixon et al. 2001). Current estimates of external nutrient loading to coastal bays are in the same range as those for deeper estuaries, even though their watersheds are significantly smaller (Table 1). Today nutrient pollution in the USA represents one of the greatest threats to the ecological integrity of coastal ecosystems (NRC 2000, EPA 2001), and it is projected to increase in the coming decades (Howarth et al. 2000, 2002). The implications to society 
Table 1. Total dissolved nitrogen (TDN) and dissolved inorganic nitrogen (DIN) loading per water body surface area. Deep estuaries are classified as $>5 \mathrm{~m}$ average depth, while shallow coastal bays are usually $<5 \mathrm{~m}$ and often $<2 \mathrm{~m}$ average depth. Sources: 1: Boynton et al. (1995); 2: Boynton et al. (1996) and references therein; 3: Seitzinger (2000) and references therein; 4: Lee \& Olsen (1985); 5: Brock (2001); 6: Buzzelli \& Christian (2001); 7: Janicki et al. (2001); 8: Nixon et al. (2001) and references therein; 9: Tomasko et al. (2001); 10: Hauxwell et al. (2003) and references therein; 11: Stanhope (2003); 12: Sigua \& Tweedale (2003); 13: Carmichael et al. (2004)

\begin{tabular}{|c|c|c|c|}
\hline System & $\begin{array}{l}\text { TDN loading } \\
\left(\mathrm{gN} \mathrm{m} \mathrm{m}^{-2} \mathrm{yr}^{-1}\right)\end{array}$ & $\begin{array}{l}\text { DIN loading } \\
\left(\mathrm{gN} \mathrm{m}^{-2} \mathrm{yr}^{-1}\right)\end{array}$ & Source \\
\hline \multicolumn{4}{|l|}{ Deep estuaries } \\
\hline Choptank River, MD & 4.3 & 2.9 & 1,3 \\
\hline Patuxent River, MD & 12.6 & 9.7 & 1,3 \\
\hline Potomac River, MD, VA & 29.3 & 18.2 & 1,3 \\
\hline Delaware Bay, DE & 18.2 & & 2 \\
\hline Narragansett Bay, RI & 27.6 & 20.2 & 2,3 \\
\hline Pamlico River, NC & 12.0 & & 2 \\
\hline Patapsco River, MD & 49.0 & & 2 \\
\hline S. San Francisco Bay, CA & 22.6 & & 2 \\
\hline Tokyo Bay, Japan & 89.1 & & 2 \\
\hline Scheldt Estuary, Netherlands & 188 & & 3 \\
\hline \multicolumn{4}{|l|}{ Shallow coastal bays } \\
\hline Albermarle Sound, NC & 7.1 & & 2 \\
\hline Apalachicola Bay, FL & 7.8 & & 2 \\
\hline Mobile Bay, AL & 17.9 & & 2 \\
\hline Assawoman Bay, MD & 4.1 & & 2 \\
\hline Chincoteaque Bay, MD & 3.1 & & 2 \\
\hline Isle of Wight Bay, MD & 6.5 & & 2 \\
\hline Sinepuxent Bay, MD & 2.4 & & 2 \\
\hline Galveston Bay, TX & & 32.9 & 3 \\
\hline Guadalupe Estuary, TX & 13.3 & 8.8 & 3 \\
\hline Ochlockonee Bay, FL & 83.9 & 22.1 & 3 \\
\hline Norsminde Fjord, Denmark & & 161.6 & 3 \\
\hline Ninigret Pond, RI & & 5.5 & 4 \\
\hline Nueces Estuary, TX & 4.6 & & 5 \\
\hline Neuse River Estuary, NC & 10 & & 6 \\
\hline Tampa Bay, FL & $3.3-8.1$ & & 7,8 \\
\hline Buttermilk Bay, MA & 19.4 & 7.7 & 8 \\
\hline Great Bay, NH & 34.2 & & 8 \\
\hline Great South Bay, NY & 4.5 & 1.5 & 8 \\
\hline Hillsborough Bay, FL & 27.4 & & 8 \\
\hline Indian River, DE & 27.6 & & 8 \\
\hline Rehoboth Bay, DE & 12.2 & & 8 \\
\hline Tomales Bay, CA & & 81 & 8 \\
\hline Itaipu Lagoon, Brazil & & 13.5 & 8 \\
\hline Guarapina Lagoon, Brazil & & 4.4 & 8 \\
\hline Urussanga Laqoon, Brazil & & 0.36 & 8 \\
\hline Flora Lagoon, Brazil & & 2.2 & 8 \\
\hline Piratininga Lagoon, Brazil & & 7.7 & 8 \\
\hline Kertinge Nor, Denmark & 4.6 & & 8 \\
\hline Randers Fjord, Denmark & 231 & & 8 \\
\hline Harvey Estuary, W. Australia & 7.7 & & 8 \\
\hline Lagoon of Venice, Italy & $30.1-36.8$ & & 8 \\
\hline Ems Estuary, Netherlands & 55.7 & & 8 \\
\hline Point Judith Pond, RI & & 5.6 & 8 \\
\hline Charlestown Pond, RI & 6.1 & & 8 \\
\hline Potter Pond, RI & & 9.5 & 8 \\
\hline Green Hill Pond, RI & & 12.7 & 8 \\
\hline Lemon Bay, FL & 4.2 & & 9 \\
\hline Childs River, MA & 40.7 & & 10 \\
\hline Eel Pond, MA & 6.3 & & 10 \\
\hline Hamblin Pond, MA & 2.8 & & 10 \\
\hline Jehu Pond, MA & 3.0 & & 10 \\
\hline Quashnet River, MA & 29.8 & & 10 \\
\hline Sage Lot Pond, MA & 0.76 & & 10 \\
\hline Timms Pond, MA & 0.53 & & 10 \\
\hline Hog Island Bay, VA & 1.0 & & 11 \\
\hline Indian River Lagoon, FL & 1.2 & & 12 \\
\hline Pleasant Bay, MA & 2.5 & & 13 \\
\hline
\end{tabular}

of this trend are significant, as coastal bays and estuaries provide critical ecosystem services, including fish and shellfish production, and human recreational activities (Costanza et al. 1997). Historically, coastal bays have been impacted less by development than large estuaries, in part because of their small size and typically limited outlets to the ocean. However, the worldwide trend for increasing human population densities along the coastline (Cohen et al. 1997) will impact coastal bays as shifts from forest to agricultural, suburban, and urban land use accelerate delivery rates of nutrients from both point and non-point sources (e.g. wastewater, agriculture, poultry farms, groundwater; Valiela et al. 1992, Nixon 1997).

Globally, coastal bay ecosystems occur on all continents except Antarctica, and are defined primarily by their very shallow depth (typically 2 to $5 \mathrm{~m}$ ); they are sometimes also referred to as lagoons or littoral zone systems. External nutrient inputs to these shallow systems are largely via groundwater and atmospheric deposition, in part due to the high ratio of sediment surface area to water volume and the lack of rivers in many systems (Giblin \& Gaines 1990, Paerl 1995). Although we have a general understanding of the consequences of eutrophication in coastal bays -including the loss of seagrasses, harmful micro- and macroalgal blooms, shifts in food web structure, increased anoxia/hypoxia, and changes in organic matter burial and degradation (Cooper \& Brush 1993, Bartoli et al. 1996, Boynton et al. 1996, Cloern 2001) — we lack sufficient knowledge of the mechanisms responsible for these patterns to have a predictive understanding of eutrophication in these shallow systems.

The development of both conceptual and quantitative models for the effects of eutrophication in coastal bays lags significantly behind that for deeper estuarine systems. Current conceptual models for eutrophication in deep estuaries link freshwater/nutrient loads and water residence times with water column properties such as phytoplankton chlorophyll and anoxic/ hypoxic volumes (Fig. 1; e.g. Scavia et al. 2004, 2006, Swaney et al. in press). Coupled ecological-hydrodynamic and statisti- 

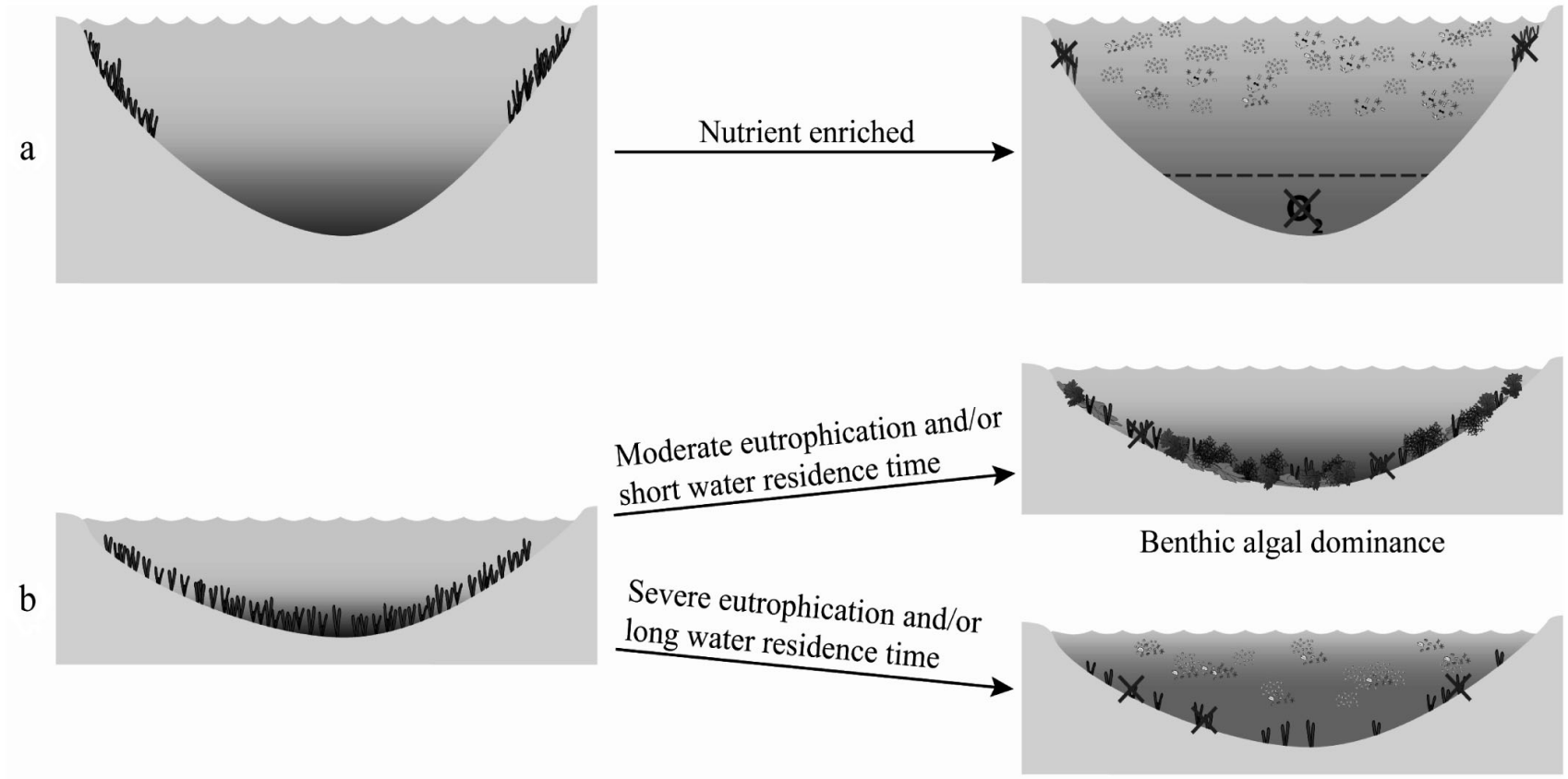

Phytoplankton dominance

Fig. 1. Conceptual models showing general effects of eutrophication in (a) deep, river-fed estuaries and (b) shallow coastal bays and lagoons. In deep estuaries, nutrient loading is correlated to phytoplankton biomass and/or volume of anoxic water, and the response is in part related to water residence time. Below the dotted line is the volume of seasonal anoxic water. In shallow bays, nutrient loading can result in an increase in macroalgal or phytoplankton biomass, depending on water residence time and the magnitude of nutrient loading. In all cases, seagrasses are lost from the photic zone due to decreased light availability caused by increased algal standing stocks. Shading reflects water transparency, with the darker areas indicating higher phytoplankton biomass

cal models are used to quantify the responses to increased nutrient loading (e.g. Cerco 1995, Hagy et al. 2004). These models have limited relevance to shallow coastal bays because coastal bays differ from deep estuaries in 2 fundamental ways: (1) the photic zone extends to most of the seafloor, and the benthos (seagrasses, macroalgae, benthic microalgae) typically dominates primary production (Valiela et al. 1997, McGlathery et al. 2001a), and (2) high rates of metabolism of benthic primary producers mediate nutrient cycling processes and result in strong benthic-pelagic coupling (e.g. Krause-Jensen et al. 1999, Tyler et al. 2001, Eyre \& Ferguson 2002). For example, because of the importance of benthic-pelagic coupling and the temporary retention of nutrients in longer-lived plant biomass (compared to phytoplankton), coastal bays often have relatively high apparent water quality (low water column nutrient concentrations, low phytoplankton biomass) even when nutrient loading rates are high for much of the year (Fig. 1; Valiela et al. 1997, McGlathery et al. 2004). Also, water column stratification typically does not occur in these shallow systems; thus, anoxia occurs in eutrophic bays as episodic events driven by the collapse of autotrophic communities, rather than as seasonal bottom water anoxia as in deep estuaries (Boynton et al. 1996). To date there are no quantitative models to predict the response of coastal bay ecosystems to increased nutrient loading.

The current conceptual model of eutrophication in coastal bays describes a change in biological structure yet little change in total system metabolism (Sand-Jensen \& Borum 1991, Duarte 1995, Boynton et al. 1996, Nielsen et al. 2004). This general model now needs to be extended to integrate both biotic feedbacks on nutrient cycling as ecological structure changes during eutrophication and the importance of water residence time and other physical processes as drivers of ecosystem response to eutrophication. In this synthesis, we first briefly review the current conceptual model of eutrophication of shallow coastal bay ecosystems. We then focus on one type of biotic feedback that influences eutrophication patterns in these systems - the important role of primary producers in the 'coastal filter', and how they influence the fate and retention of watershed nutrients on their trajectory to the open ocean. We discuss the 2 aspects of plant-mediated nutrient cycling as eutrophication induces a shift in primary producer dominance: (1) the fate of nutrients bound in plant biomass, and (2) the effects of primary producers on biogeochemical processes that influence nutrient retention. 


\section{CURRENT CONCEPTUAL MODEL}

The conceptual model of eutrophication in shallow coastal bays describes a shift in dominance from seagrasses and perennial macroalgae to ephemeral, bloom-forming macroalgae and epiphytes (SandJensen \& Borum 1991, Duarte 1995, Valiela et al. 1997), and ultimately, to phytoplankton dominance in the most heavily eutrophied systems (Duarte 1995, Valiela et al. 1997) (Fig. 1). This represents a shift from large benthic macrophytes with relatively high light requirements, high biomass per unit area, and low nutrient turnover rates to algae with lower light requirements, low biomass per unit area, and high nutrient turnover rates (e.g. Duarte 1995, Taylor et al. 1995, Borum 1996). It should be noted that very little attention has been paid to the relative importance of benthic microalgae as systems become eutrophied (Sand-Jensen \& Borum 1991). Benthic microalgae have a relatively high tolerance to hypoxia and anoxia (Sundbäck et al. 1990), sulfide (Admiraal 1984, Kennet \& Hargraves 1985), and long periods of darkness (Gargas \& Gargas 1982, Sundbäck \& Graneli 1988), which suggests that they may be important in the resilience to, and recovery from, eutrophication (Sundbäck \& McGlathery 2005). Also, a better understanding of eutrophication effects in tropical systems is needed to refine the model. For example, there is evidence that in the more speciose and oligotrophic tropical systems, nutrient enrichment may cause a shift in seagrass dominance (Fourqurean et al. 1995, Udy \& Dennison 1997) and enhance seagrass production and areal coverage (Udy et al. 1999) before a shift to algal dominance occurs.

Ultimately, the increased decomposition of autotrophs in heavily eutrophied systems will cause the sediments to become increasingly heterotrophic (Borum \& Sand-Jensen 1996). This will result in a higher nutrient efflux from the sediment to the water column, which will cause accelerating eutrophication through internal loading of nutrients (e.g. Rizzo et al. 1992, Meyercordt \& Meyer-Reil 1999, Eyre \& Ferguson 2002). Sulfide concentrations increase as a result of high sulfate reduction rates during decomposition, and high sulfide levels will have an inhibitory effect on macrophytes, macrofauna, and on some biogeochemical processes such as coupled nitrification/denitrification (Sorensen et al. 1980, Joye \& Hollibaugh 1995, Chambers et al. 2003). Changes in benthic faunal communities as the sediments become more anoxic and sulfidic will also feed back to influence redox conditions and $\mathrm{N}$ cycling processes in the sediment (Diaz \& Rosenberg 1995, Grall \& Chauvaud 2002).

Within this general conceptual framework, there is also a suggestion that water residence time is a key factor influencing whether phytoplankton or macroalgae contribute the most to total production as systems become eutrophied, with longer residence times favoring phytoplankton dominance (Fig. 1; Valiela et al. 1997, 2000, Oberg 2005). The assumption is that because phytoplankton can grow before being flushed from the system, they can outcompete benthic algae via shading effects. However, Nixon et al. (2001) failed to find predictive relationships between nutrient loading and the dominance of macroalgae versus phytoplankton in a recent review of 30 shallow coastal systems with varying nitrogen $(\mathrm{N})$ input rates from 1 to $230 \mathrm{~g} \mathrm{~N} \mathrm{~m}^{-2} \mathrm{yr}^{-1}$ and hydraulic residence times from 0.3 to $100 \mathrm{~d}$, or in lagoon mesocosm studies. Several factors may be responsible for this lack of pattern in addition to the high interannual variation noted by Nixon et al. (2001). These include grazing, tidal amplitude, and the relative importance of internal nutrient loading. High tidal amplitude in estuaries tends to lower phytoplankton biomass for a given nutrient load (Monbet 1992). This is perhaps due to increased sediment resuspension and decreased light availability (Monbet 1992) or to tidal breakdown of stratification in some systems like San Francisco Bay that may facilitate grazing by benthic suspension feeders (Alpine \& Cloern 1992). Also, regardless of tidal amplitude or water residence time, benthic algae can outcompete phytoplankton for nutrients if the major nutrient supply is internal loading from mineralization in the sediments. Active macro- and micro-algal mats uncouple sediment biogeochemical cycling from water column processes, and reduce the flux of remineralized nutrients from the sediment to the overlying water (e.g. Sundbäck et al. 1991, McGlathery et al. 1997, Anderson et al. 2003, Tyler et al. 2003), which limits the supply of nutrients for phytoplankton growth. Short-lived phytoplankton blooms that occur in these systems often coincide with low benthic algal biomass (Sfriso et al. 1992, Valiela et al. 1992, McGlathery et al. 2001a).

Increased micro- and macro-algal standing stocks during eutrophication lead to a decline in the depth limit and abundance of seagrasses and perennial macroalgae (Kautsky et al. 1986, Abal \& Dennison 1996, Short et al. 1995, Nielsen et al. 2002). One report suggests that $60 \%$ of the global seagrass loss is due to nutrient loading related to anthropogenic activities (Short \& Wyllie-Escheverria 1996). We know from field observations and experimental mesocosm studies that much of this decline is due to a reduction in light availability and altered biogeochemical conditions from increased algal standing stocks (as macroalgae, epiphytes and/or phytoplankton; Twilley et al. 1985, Neckles et al. 1994, Short et al. 1995, Taylor et al. 1995, Hauxwell et al. 2001, 2003, Nixon et al. 2001). Epiphytes attenuate up to $90 \%$ of the light at the scale of 
the seagrass blade (Sand-Jensen 1977, Howard \& Short 1986, Brush \& Nixon 2002). Bloom-forming macroalgae form dense canopies up to $1 \mathrm{~m}$ thick over seagrass beds in eutrophic waters and can also decrease light levels by $>90 \%$ in the upper few centimeters of the mat (Krause-Jensen et al. 1996, Peckol \& Rivers 1996, Astill \& Lavery 2001). Shading by increased algal standing stocks reduces the photosynthetic oxygen production of seagrasses, which decreases oxygen translocation and release to the rhizosphere (Goodman et al. 1995, but see Terrados et al. 1999). The high concentrations of sulfide that develop in the rhizosphere decrease nutrient uptake and plant energy status (Pregnall et al. 1984), and result in further reductions in photosynthesis, growth, and leaf density, and sometimes, eventual mortality (Goodman et al. 1995, Holmer \& Bondgaard 2001). In addition, oxygen depletion and high ammonium $\left(\mathrm{NH}_{4}^{+}\right)$concentrations that typically result from mineralization in the lower layers of dense macroalgal mats can cause seagrass mortality, especially for new shoots that may exist completely within the anoxic layer (Krause-Jensen et al. 1996, McGlathery et al. 1997, Hauxwell et al. 2001). Greve et al. (2003) showed that the meristematic tissue at the base of the seagrass leaf is particularly sensitive to anoxia, presumably because this tissue lacks the physiological adaptations that exist in roots and rhizomes to deal with anoxia.

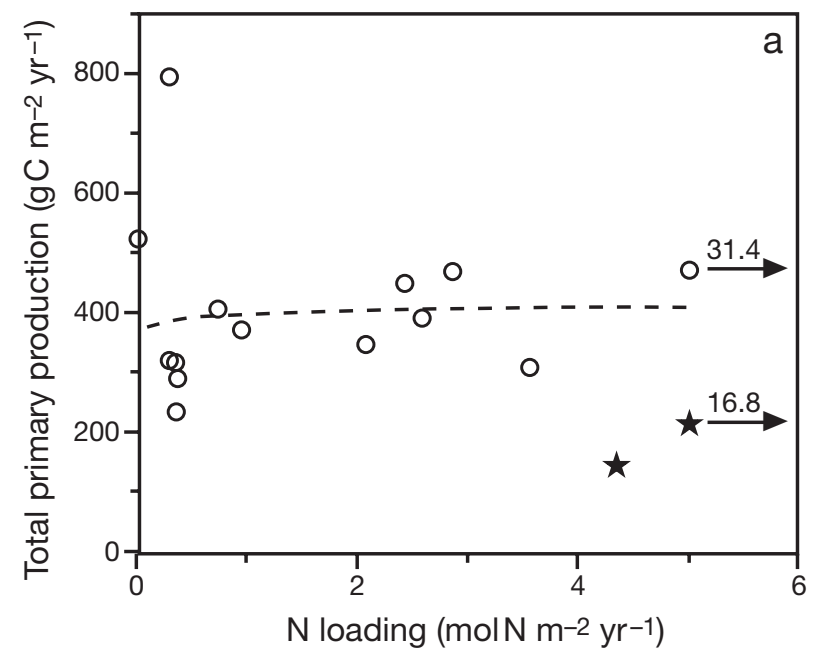

Fig. 2. Relationships between (a) total primary production and $\mathrm{N}$ loading and (b) benthic and pelagic production in shallow coastal ecosystems (from Borum \& Sand-Jensen 1996). Arrows indicate data points that are off the scale; stars indicate data (from highly turbid estuaries) which were not included in the regression
Even though there is a shift in the relative contribution of the different plant groups to total primary production when shallow systems are eutrophied, there is some evidence from comparative studies that total primary production $\left(\mathrm{gC} \mathrm{m}^{-2} \mathrm{yr}^{-1}\right)$ does not change (Fig. 2a; Borum \& Sand-Jensen 1996, Nixon et al. 2001). This is in contrast to deeper systems where eutrophication enhances phytoplankton production and results in increased total system production (Cloern 2001 and references therein). This difference is due to the switch between benthic and pelagic production as eutrophication proceeds in shallow coastal bays (Borum \& Sand-Jensen 1996). There may be a small initial increase in total production as fast-growing algae are stimulated but seagrasses still survive, but as phytoplankton ultimately replace benthic macrophytes, total production appears to remain relatively stable (Fig. 2b).

As ecological structure changes, biotic feedbacks of primary producers at the local scale are important determinants of the response to eutrophication (1) directly through uptake, and the fate of plant-bound nutrients via mineralization and long-term retention of recalcitrant organic matter in sediments, grazing, and advection; and (2) indirectly through the influence on physicochemical conditions that affect bacterially- and chemically-mediated nutrient transformations such as

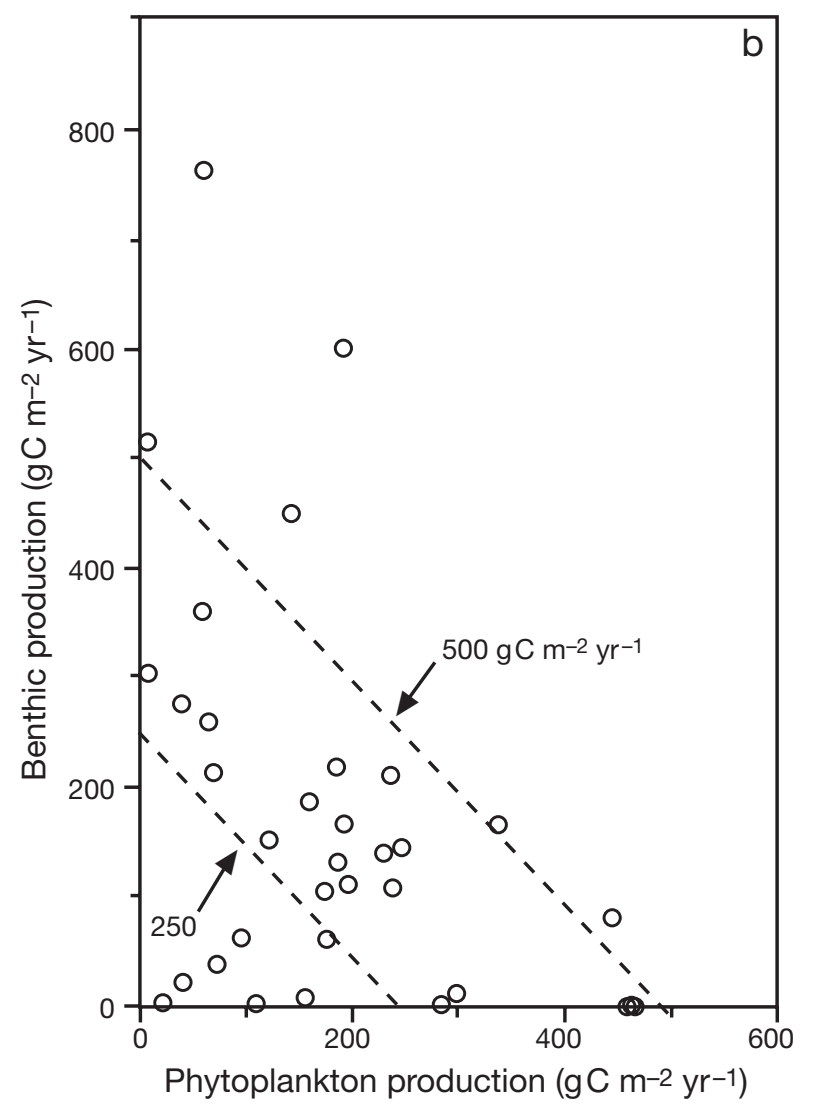


mineralization, nitrification, denitrification, $\mathrm{N}$ fixation, dissimilatory nitrate reduction to ammonium (DNRA), anaerobic ammonium oxidation (anammox), sediment diagenesis and sorption/desorption characteristics of the sediments. Variations in the rates and dominance of these processes will influence the retention of watershed nutrients on their trajectory to the open ocean.

\section{BIOTIC FEEDBACKS - THE ROLE OF PLANTS IN THE 'COASTAL FILTER'}

\section{Direct effects}

Temporary retention in plant biomass

Pedersen et al. (2004) estimated the combined annual $\mathrm{N}$ and phosphorus (P) assimilation by microalgae, macroalgae and rooted macrophytes in 18 shallow temperate systems and found that assimilation by primary producers was similar to, or in excess of, external nutrient inputs to the systems as long as nutrient loadings were less than about $50 \mathrm{gN} \mathrm{m}^{-2} \mathrm{yr}^{-1}$ and
$5 \mathrm{gP} \mathrm{m}^{-2} \mathrm{yr}^{-1}$ (Fig. 3). Most of the $\mathrm{N}$ loading rates for shallow coastal bays reported in Table 1 are below this value, suggesting that most nutrients entering coastal bay ecosystems pass through the primary producer communities. Interestingly, though biomass and production rates vary substantially among the primary producer groups, the magnitude of nutrient assimilation may not be tremendously different (Table 2; K. J. McGlathery, A. C. Tyler, M. S. Thomsen \& P. Berg unpubl.). These similar rates imply that the turnover time and fate of nutrients bound in plant tissue have a key influence on the role of primary producers in nutrient retention.

Nutrients that are assimilated by plants as systems become eutrophied are, for the most part, only temporarily retained in the system on a time scale of days to months. Tissue turnover times vary for the different autotrophs, with seagrasses having longer retention time (weeks to months) than bloom-forming macroalgae (days to weeks) and microalgae (days). Most of the nutrients bound in plant tissue will ultimately become available through leakage from live tissue, remineralization, transfer to microbial and grazing trophic
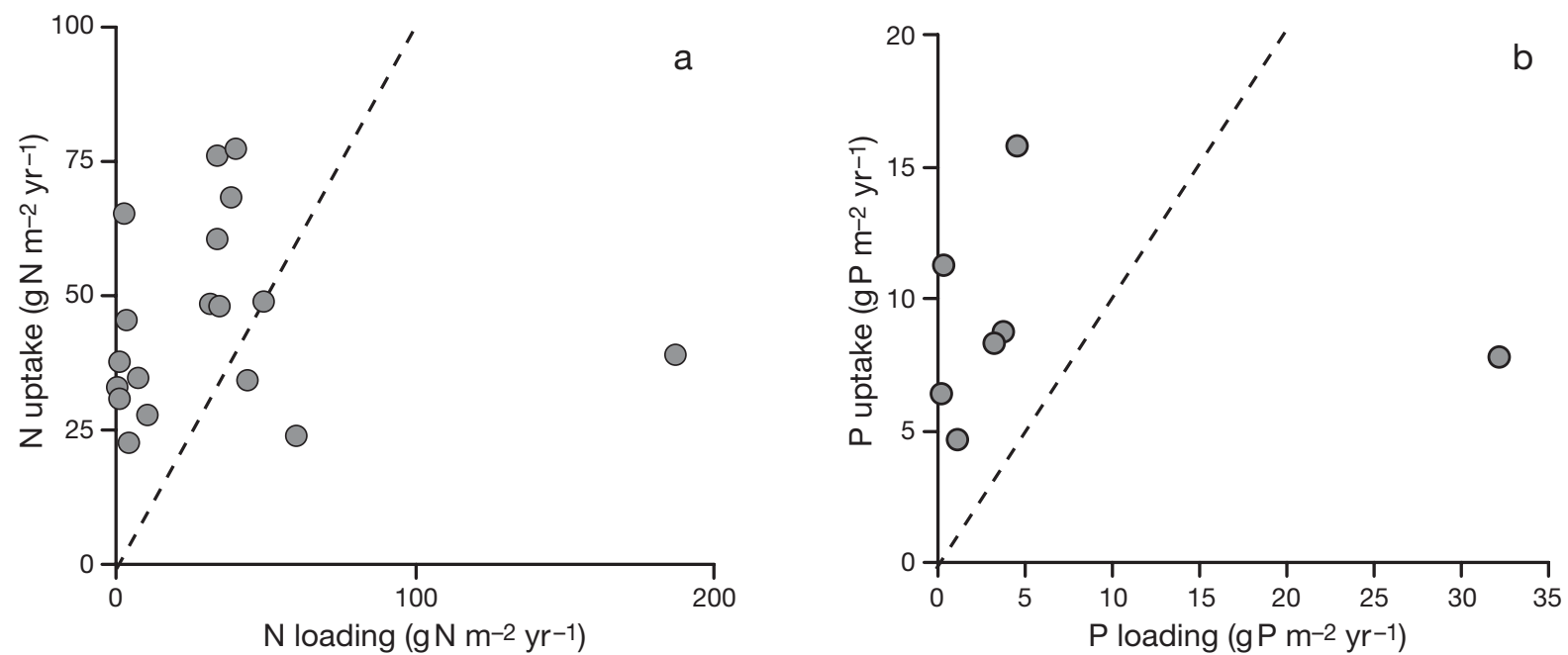

Fig. 3. Relationships between loading and nutrient uptake by all autotrophs in various shallow coastal ecosystems for (a) nitrogen and (b) phosphorus (from Pedersen et al. 2004)

Table 2. Calculated nitrogen assimilation of benthic microalgae (BMA), macroalgae (MA), and phytoplankton in the temperate coastal bay, Hog Island Bay, Virginia. Shown are seasonal mean rates at 3 sites that represent a mainland to barrier island transect across the bay. Benthic microalgal and phytoplankton nitrogen assimilation rates are calculated from $90 \%$ gross primary production (Ass $\mathrm{GPP}_{\mathrm{GP}}$ ), using a C:N ratio of 9 for benthic microalgae and 6.6 for phytoplankton. Macroalgal $\mathrm{N}$ assimilation is based on growth, calculated as an increase of biomass, and measured C:N ratios. Units are $\mathrm{mmolN} \mathrm{m}^{-2} \mathrm{~d}$. Data from K. J. McGlathery, A. C. Tyler, M. S. Thomsen \& P. Berg (unpubl.)

\begin{tabular}{|c|c|c|c|c|c|c|c|c|c|c|c|c|}
\hline & \multirow[b]{2}{*}{ BMA } & \multicolumn{2}{|c|}{ Winter -} & \multicolumn{3}{|c|}{ Spring -} & \multicolumn{3}{|c|}{ - Summer } & \multicolumn{3}{|c|}{ Fall } \\
\hline & & MA & Plankton & BMA & MA & Plankton & BMA & MA & Plankton & BMA & MA & Plankton \\
\hline Mainland creeks & 3.02 & 0.50 & 0 & 0.32 & 0.43 & 0.24 & 2.63 & 0.51 & 1.12 & 5.27 & 0.13 & 0.56 \\
\hline Mid-lagoon shoals & 1.98 & 1.00 & 0 & 1.83 & 1.14 & 0.31 & 0.84 & 6.17 & 2.28 & 2.71 & 1.85 & 1.14 \\
\hline Barrier islands & 1.38 & 0.11 & 0 & 1.18 & 0.07 & 0 & 4.55 & 0.33 & 2.15 & 3.07 & 0.16 & 1.08 \\
\hline
\end{tabular}


levels, and subsequent excretion by grazers (Duarte \& Cebrián 1996, Cerco \& Seitzinger 1997, Cebrián 2002); some is retained over longer $(>1 \mathrm{yr})$ time scales. The timing of the short-term temporary retention is important as it can slow the seaward transport of nutrients and reduce nutrient availability for other autotrophs during the growing season. For example, nutrients that were temporarily retained in Zostera marina leaf tissue in a Danish coastal bay were either nearly completely mineralized (95 to $98 \%$ ) in the fall when the negative effects of anoxia from stimulated phytoplankton blooms were less likely to occur, or were lost when the leaves were detached and transported from the system (Risgaard-Petersen \& Ottosen 2000). Similarly, for macroalgae, $\mathrm{N}$ temporarily retained in plant tissue provides a short-term buffer to nutrient loading effects in the water column; however, most of this is released during senescence over a period of several weeks to several months (Buchsbaum et al. 1991, Tyler et al. 2001). Many macroalgal blooms go through 'boom and bust' cycles, with mid-growing season population crashes due to high temperatures and self-shading within macroalgal mats. Benthic microalgae are present and active throughout the year (Rizzo et al. 1996 and references therein), and their relative importance for nutrient turnover depends on the presence, seasonal pattern and areal coverage of other primary producers that can shade the sediment, as well as physical factors such as sediment resuspension and pore water advection (Asmus \& Asmus 1985, McGlathery et al. 2001a).

\section{Fate of plant-bound nutrients}

Decomposition and retention in recalcitrant material. Incomplete or slow decomposition of organic matter could contribute material for long-term (decadal) retention of nutrients via sediment accumulation. Also, bacterial processing of dissolved organic matter (DOM) released during decomposition may result in the release of bacteria-specific organic matter such as D-alanine, which is less labile than plant-derived organic matter (Veuger et al. 2006). The long-term retention of nutrients in particulate or dissolved forms that are recalcitrant and less available to support further primary production is an important biotic feedback as community structure changes during eutrophication.

Detritus from microalgae (pelagic and benthic) and ephemeral macroalgae that both have relatively little structural tissue and high nutrient content tend to decay faster than slow-growing perennial macroalgae and seagrasses (Buchsbaum et al. 1991, Enriquez et al. 1993, Banta et al. 2004). This suggests that nutrients will be recycled faster in systems dominated by micro- algae and ephemeral macroalgae than in those dominated by perennial macrophytes (Duarte 1995). Mineralization rates of $\mathrm{N}$ and $\mathrm{P}$ may be different than those for carbon (C) or total mass and this is likely due to differences in nutrient content of the detritus (Banta et al. 2004). More work is needed on net mineralization rates of $\mathrm{N}$ and $\mathrm{P}$ bound in tissue of the different primary producer groups and in sediment in order to determine the potential for long-term nutrient retention in shallow coastal systems.

Since most algal and seagrass leaf detritus decomposes on a relatively short time scale (days to months), the presence of a refractory pool in the detritus is suggested to be the main determinant of the potential for long-term retention in shallow systems (Duarte \& Cebrián 1996, Cebrián 1999, Banta et al. 2004). In a review of over 100 published data sets, Banta et al. (2004) showed that all types of detritus, including microalgae, typically contain some refractory pools that could contribute to long-term nutrient retention. The slower and more incomplete decomposition of perennial macrophyte tissue, particularly the seagrass roots and rhizomes, likely leads to the most significant organic matter and nutrient accumulation in sediments. Banta et al. (2004) found that over $50 \%$ of Zostera marina root and rhizome detritus and $15 \%$ of leaf detritus remained after nearly 2 yr of a litter bag experiment. However, the majority of the organic matter and nutrient accumulation in some seagrass-vegetated sediments can be attributed to imported allochthonous material (Boschker et al. 2000, Gacia et al. 2002). Seagrass canopies reduce water current velocities and promote deposition, particularly of fine, organic-rich particles (Kenworthy et al. 1982, Benoy \& Kalff 1999, Gacia et al. 2002), and also reduce particle resuspension and erosion, which further enhances sediment accumulation (Middelburg et al. 2004). Benthic microalgae (particularly diatoms) in seagrass-vegetated sediments also enhance sediment stability by producing biofilms of extracellular polymeric substances that reduce sediment erodability (Madsen et al. 1993, Underwood \& Paterson 1993, de Brouwer et al. 2000). This sediment stabilization, however, is a seasonal phenomenon at least in temperate systems, and the deposited material may be resuspended at times of the year when the microalgae are less productive (Middelburg et al. 2004). More work is needed on the effects of benthic microalgae on sediment organic matter and nutrient accumulation, particularly in tropical systems where they may be highly productive throughout the year. Although benthic microalgae are effective at retaining remineralized nutrients when productive, given the smaller pool of recalcitrant material in benthic microalgae, it is likely that their contribution to long-term nutrient retention is small compared to seagrasses. 
These studies suggest the main impact of eutrophication on long-term nutrient retention (as recalcitrant material in coastal bays) is the loss of seagrasses (Fig. 4a). At low external nutrient loading rates, uptake and retention of nutrients in seagrass biomass, and the subsequent accumulation of the relatively large refractory component of this tissue in the sediments, can act as a natural buffering mechanism to enhanced nutrient
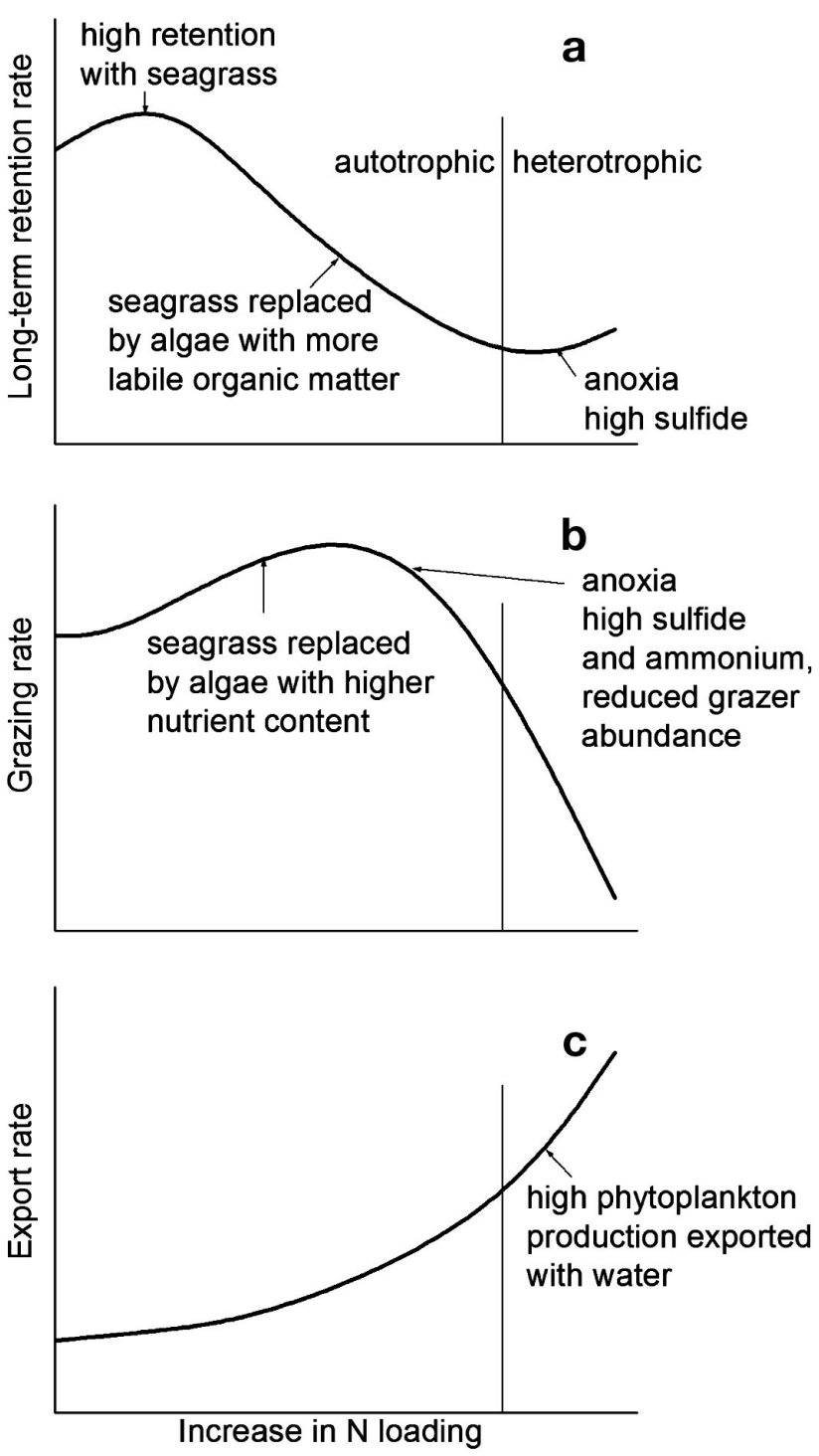

Fig. 4. Conceptual model of hypothetical changes in the fate of nitrogen bound in plant biomass in relation to shifts in autotroph community composition as nitrogen loading is increased and sediments and the overlying water (including the macrophyte canopy) ultimately become heterotrophic for (a) long-term retention in sediments, (b) grazing, and (c) export. Evidence suggests that the magnitude of nutrient assimilation by the autotrophs is of similar magnitude to nutrient loading rates, suggesting that the autotrophs are an important part of the coastal filter loading (de Wit et al. 2001). This buffering is reduced as seagrasses are replaced by fast-growing algae and nutrient turnover increases. Decomposing macroalgal mats contribute significant amounts of organic matter to the sediments (Trimmer et al. 2000, Tyler et al. 2003), and this temporarily increases nutrient retention in the sediments, although over a shorter time scale than for seagrasses. Tyler et al. (2001) reported that dissolved N release rates from sediments following the collapse of a macroalgal bloom (650 g [dry weight] $\mathrm{m}^{-2}$ ) were sufficient to completely mineralize the macroalgal biomass within 2 wk. Burial and retention rates may even be reduced before a major shift in plant communities occurs. Perez et al. (2001) found a net accumulation of $\mathrm{N}$ and $\mathrm{P}$ in slowly-degrading below-ground detritus in N-limited Cymodocea nodosa seagrass beds, but in eutrophic waters where below-ground production was reduced and decay rates of N-rich leaves were high, the seagrass meadow became a source of nutrients to the water column. The more rapid turnover of nutrients in eutrophic algal-dominated systems functions as a positive feedback mechanism that increases nutrient availability to sustain large algal standing stocks.

When sediments become anoxic in the most eutrophied systems, there may be a slight increase in nutrient retention in sediments due to the slower decomposition of refractory material under anoxic conditions and the loss of bio-irrigating and bioturbating benthic fauna (Kristensen et al. 1995, Kristensen 2000). However, the organic matter deposited on the sediments during this stage of eutrophication would be mostly labile material derived from phytoplankton or fast-growing macroalgae, and anoxia appears to have little effect on the decomposition of this labile fraction (Middelburg et al. 2004). Another factor that may influence nutrient retention in anoxic sulfidic sediments is an increased rate of DNRA and potential $\mathrm{NH}_{4}{ }^{+}$uptake by bacteria and burial of bacterial biomass. We need more information on the relative importance of this process during eutrophication to understand the changes in long-term nutrient retention as sediments become heterotrophic.

Grazing. The response of the primary producer community to eutrophication in coastal bays may be modulated by benthic herbivory. Numerous experimental and observational studies from coastal bays indicate the capacity of a variety of benthic grazers including filter-feeding bivalves, ascidians, sponges, polychaetes, amphipods, gastropods, and small herbivorous fish to buffer the effects of nutrient enrichment (e.g. Alpine \& Cloern 1992, Neckles et al. 1993, Williams \& Ruckelshaus 1993, Lin et al. 1996, Heck et al. 2000, Hillebrand et al. 2000, Lotze \& Worm 2002, Heck \& Valentine 2007). For example, dense populations of filter-feeding bivalves limit the accumulation of phyto- 
plankton under non-stratified conditions in San Francisco Bay (Alpine \& Cloern 1992). Mesograzers (e.g. amphipods and gastropods) can control the abundance of algal epiphytes on seagrasses and hard substrates even under moderate nutrient loading (Neckles et al. 1993, Williams \& Ruckelshaus 1993, Hillebrand et al. 2000, Lotze \& Worm 2002). Likewise, macroalgal responses to eutrophication, and the shading impact of macroalgal blooms on seagrasses, may be mediated by grazing (Worm et al. 2000, Hauxwell et al. 2001). Preferential feeding by herbivores can influence algal abundance and species composition (e.g. Duffy \& Harvilicz 2001, Duffy et al. 2003, Cebrián 2004); however, we know relatively little about the implications of this for the storage and trophic transfer of nutrients as systems become eutrophied (Duffy et al. 2003).

From large-scale comparative studies, we know that grazing intensity can be highly variable, both within and between primary producer groups (Duarte \& Cebrián 1996, Cebrián 2002). Many studies show an association between high nutrient content of the primary producers and high consumption rates (Horn 1989, McGlathery 1995, Cebrián 1999 and references therein, Goecker et al. 2005); however, other factors such as herbivore abundance, per capita grazing rates of the dominant herbivores, and feeding preferences also play important roles in determining patterns of herbivory (Cebrián 2004 and references therein). Based on these factors, we would expect a unimodal pattern of relative grazing rate in response to elevated nutrient loading (Fig. 4b).

In general, herbivores consume a smaller percentage of primary production in seagrass communities compared to macro- and micro-algal communities (Cebrián 2004 and references therein), and this appears be at least in part due to the lower nutrient content of seagrass leaves. However, the study by Valentine \& Heck (2001) shows evidence of compensatory feeding in urchins, where urchins increased feeding on leaves with low $\mathrm{N}$ to meet their nutritional demands. More information is needed on how other aspects of plant nutritional quality, such as chemical deterrents, influence herbivory in systems with different nutrient status. As the dominance in benthic communities shifts to bloom-forming macroalgae and epiphytes during eutrophication, one would expect a higher proportion of primary production to be channeled through the herbivores. At some point, enhanced algal growth from high nutrient loading will saturate grazing potential and decrease per capita consumption rates; grazer abundance will also be negatively impacted by the changes in physicochemical conditions (i.e. low oxygen, high sufide and $\mathrm{NH}_{4}^{+}$) that result from the decomposition of algal blooms (Hauxwell et al. 1998, Rosinski 2004). The increase in phytoplankton biomass that occurs during eutrophication of some systems may support higher filter-feeder biomass until their filtration capacity is exceeded and the increase in organic matter decay causes anoxia and mortality of filter feeders (Cloern 2001). Grazing of phytoplankton by benthic suspension feeders can buffer the initial effects of eutrophication as long as water residence time is longer than the clearance time of the filter feeders or the systems are not stratified (Haamer 1996, Haamer \& Rohde 2000). We would expect the lowest consumption to occur in the most eutrophied systems where anoxia, sulfide and $\mathrm{NH}_{4}{ }^{+}$concentrations negatively impact consumer populations (Fig. 4b).

The grazing impact on benthic microalgae as eutrophication proceeds is less clear. A large part of benthic microalgal production is thought to pass through the macrofaunal grazing/deposit feeding chain (Asmus \& Asmus 1985, Duarte \& Cebrián 1996, Herman et al. 2000), while part of it may also be channeled through the 'small food chain' consisting of micro- and meiofauna (Kuipers et al. 1981, Sundbäck et al. 1996, Pinckney et al. 2003). However, since much of the organic matter is released as DOM by live and dead material (Goto et al. 1999, Wolfstein et al. 2002), processing of particulate organic matter by grazers and bacteria may only account for a portion of the total carbon fixed by benthic microalgae. During the initial stage of eutrophication, grazing of benthic microalgae by meiofauna can be expected to increase (Nilsson et al. 1991), however, we still lack a clear understanding of how grazing modulates the benthic microalgal response to nutrient loading (Hillebrand \& Kahlert 2002).

Export. Plant material that is not decomposed in situ, retained through long-term retention, or grazed may be lost from the system via mass transport. Seagrass leaves are transported primarily at the water surface due to their extensive aerenchyma tissue, whereas macroalgal material moves either as bedload or as floating mats at the water surface, depending on their specific gravity (which is influenced by invertebrates that colonize mat-forming macroalgae). Most of the bloom-forming macroalgae (e.g. Ulva sp., Chaetomorpha sp., Enteromorpha sp., Gracilaria sp., Polysiphonia sp.), live unattached or loosely attached to hard surfaces (i.e. bivalve shells, worm tubes) on the sediment (Schories \& Reise 1993, Thomsen \& McGlathery 2005). Transport of plant-bound nutrients is often not included in mass balance calculations of shallow coastal systems in part because of the difficulty in doing representative sampling. Unattached, living macroalgae move at water current velocities as low as $2 \mathrm{~cm} \mathrm{~s}^{-1}$ (Flindt et al. 2004, Thomsen 2004), and these current velocities are common in shallow coastal bays where both winds and tides affect current speeds at the sediment surface (Lawson et al. 2007). Macroalgae also settle 1000 to 5000 times faster 
than phytoplankton, and hence if transported out of coastal bays, usually settle on the ocean floor rather than being returned on the flood tide (Flindt et al. 2004). Seagrasses settle more slowly than macroalgae due to the air-filled arenchyma tissue, and their surface movements are influenced by wind speed and direction as well as current speed. Few studies include mass transport of nutrients bound in plant material, and this can cause significant overestimates of nutrient retention in coastal bays. For example, Flindt et al. (2004) determined that for 2 European systems (Venice Lagoon, Italy, and Roskilde Fjord, Denmark), the exclusion of mass transport of plant tissue nutrients would lead to an overestimate of $\mathrm{N}$ retention by 18 to $60 \%$ and P retention by 23 to $44 \%$.

As eutrophication proceeds, the potential for export of plant-bound nutrients on an annual basis will likely increase by at least 2 mechanisms as the plant community shifts (Fig. 4c). First, algal shading, anoxia or high sulfide levels will stress seagrasses and increase the rate at which leaves are sloughed and, thus, the potential for export (Holmer \& Bondegaard 2001, Greve et al. 2003). Second, ephemeral macroalgae that displace rooted seagrasses and perennial algae with strong holdfasts have lower erosion thresholds and will more likely be moved and transported from the system at lower current speeds. Nutrient loss via export should be most pronounced in highly eutrophic systems where phytoplankton dominate and simply move with the water. It has also been suggested that export may constitute a major fate of benthic microalgal production (Admiraal 1984, de Jonge \& van Beusekom 1996). Clearly, other physical characteristics of the system, such as the degree of exchange with the ocean and water residence times, will influence advective transport of all plant types, but studies quantifying the effects of physical factors on export of plant material are few. Fish and other mobile fauna may also be important vectors of nutrients (and energy) from coastal systems, but are rarely studied. One example is a study by Deegan (1993), which showed that $\mathrm{N}$ and $\mathrm{P}$ export by gulf menhaden from a Louisiana estuary to the nearshore Gulf of Mexico was of the same magnitude as passive waterborne export of dissolved inorganic nitrogen (DIN) and phosphorus (DIP), and that carbon export accounted for approximately 5 to $10 \%$ of the total primary production.

\section{Indirect effects}

Modification of physicochemical environment by benthic plants

The indirect effects of primary producers on nutrient cycling are mediated by photosynthetic oxygen pro- duction and leakage of DOM. Seagrasses leak both oxygen and DOM from the roots, and this is driven by photosynthesis. Oxygen is transported from the leaves to the roots to support aerobic respiration via a welldeveloped lacunal system, a series of air channels comprising up to $60 \%$ of the total plant volume. The oxygen that is not respired by the roots is released into the rhizosphere, creating oxidized micro-zones (<100 $\mathrm{mm}$ from root surface) where reduced iron and sulfur may be reoxidized (Greve et al. 2003, Fredricksen \& Glud 2006). DOM released from the roots as simple organic carbon compounds (Koepfler et al. 1993, Ziegler \& Benner 1999) has been shown to stimulate bacterial activity in the rhizosphere (e.g. Moriarty et al. 1986, Welsh et al. 1996, McGlathery et al. 1998, Blaabjerg et al. 1998). The release of oxygen and DOM also influences the forms and availability of sediment $\mathrm{P}$, and this is especially important in carbonate sediments of the tropics and subtropics where primary production is often limited by P (Jensen et al. 1998, Burdige \& Zimmerman 2002). Photosynthesis and respiration by benthic microalgae in the top few millimeters of the sediments cause large diel variations in oxygen concentrations and penetration depth, dissolved inorganic carbon (DIC) concentrations and pH (e.g. Glud et al. 1999). The steep and dynamic oxygen gradients created by benthic microalgal activity affect the vertical position and rates of redox-sensitive processes such nitrification, denitrification, DNRA, anammox and reduction of Mn, Fe and sulfate (e.g. Risgaard-Petersen 2003 and references therein). Within macroalgal mats, variations in light availability, and in nutrient, oxygen, and $\mathrm{pH}$ conditions linked to algal photosynthesis, respiration, and decomposition, influence nutrient cycling at the sediment-water interface, and perhaps even deeper into the sediments. The presence of dense macroalgal mats can move the location of the oxicanoxic interface up from the sediments into the macroalgal mat, since usually macroalgae in only the upper few centimetres of the mat are in the photic zone and are actively productive (Krause-Jensen et al. 1999, Astill \& Lavery 2001). Sediment nutrient cycling also is enhanced by the presence of macroalgae, presumably due to the input of organic matter (Trimmer et al. 2000, Tyler et al. 2003).

\section{Effects of plants and their decomposition on biogeochemical processes}

Nitrogen cycling. Nitrogen cycling processes in sediments are regulated primarily by concentrations of oxygen, sulfide and dissolved organic carbon (DOC), and by competition with benthic autotrophs for substrate. The relative importance of denitrification, 


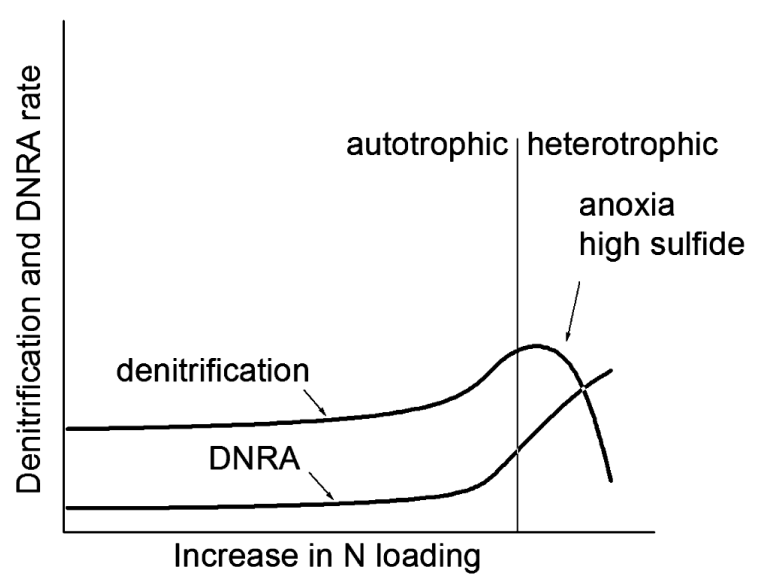

Fig. 5. Conceptual model of hypothetical changes in denitrification and dissimilatory nitrate reduction to ammonium (DNRA) rates during eutrophication that are indirectly affected by the changes in dissolved organic matter, oxygen and sulfide concentrations in the sediments caused by the benthic autotrophs, and as the sediments and the adjacent water column (including the macrophyte canopy) ultimately become heterotrophic

anammox and DNRA, all processes requiring anoxic conditions, determines to some extent the degree to which $\mathrm{N}$ is retained in sediments, since denitrification and anammox result in net loss whereas DNRA retains $\mathrm{N}$ as $\mathrm{NH}_{4}{ }^{+}$.

Denitrification is not likely to be a significant sink of external nutrient inputs in most shallow bays with pho- tosynthetically-active benthic populations when external nutrient loading is low to moderate (Fig. 5). These low and invariable rates are expected for 2 reasons: (1) In general, most benthic primary producers do not stimulate coupled nitrification-denitrification in $\mathrm{N}$ limited systems because they outcompete bacteria for DIN (Rysgaard et al. 1995); this is described in more detail below. (2) There does not appear to be a large difference in the effect of different primary producers on denitrification rates (Table 3), so a shift in biological structure of the autotrophic community will not measurably affect denitrification rates. This is different from the scenario for deep estuaries where denitrification increases in proportion to $\mathrm{N}$ loads during the early to mid stages of eutrophication (Nixon et al. 1996).

Although some studies show enhancement of coupled nitrification-denitrification in the seagrass rhizosphere (Potamogeton perfoliatus and Zostera marina; Caffrey \& Kemp 1992, Flindt 1994, Cornwell et al. 1999), seagrasses in general appear to suppress nitrification-denitrification in the rhizosphere relative to bare sediments (Rysgaard et al. 1996, RisgaardPetersen \& Ottosen 2000, Risgaard-Petersen 2004). This is attributed to low rates of nitrification in the oxic microzones surrounding the roots and to competition for $\mathrm{NH}_{4}^{+}$between nitrifying bacteria and benthic microalgae (Ottosen et al. 1999, Risgaard-Petersen \& Ottosen 2000). There are relatively few measurements of denitrification in seagrass-vegetated carbonate sed-

Table 3. Comparison of denitrification rates (including range of light and dark values) for sediments associated with different benthic autotrophs in temperate and tropical/subtropical coastal bays

\begin{tabular}{|c|c|c|c|}
\hline Dominant autotroph & Location & 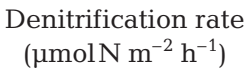 & Source \\
\hline \multicolumn{4}{|l|}{ Temperate } \\
\hline \multicolumn{4}{|l|}{ Seagrass } \\
\hline Zostera marina & Limfjord, Denmark & 16.7 & Risgaard-Petersen et al. (1998) \\
\hline Zostera noltii & Arcachon Bay, France & $2.1-5.8$ & Welsh et al. (2000) \\
\hline Zostera noltii & Arcachon Bay and Etang du Prevost, France & 13.8 & Rysgaard et al. (1996) \\
\hline Zostera capricorni & Edmunds Bay, Australia & 7.9 & Eyre \& Ferguson (2002) \\
\hline \multicolumn{4}{|l|}{ Macroalgae } \\
\hline Chaetomorpha linum & Kertinge Nor, Denmark & $22-28$ & Krause-Jensen et al. (1999) \\
\hline Enteromorpha sp., Ulva sp. & Langstone and Chichester Harbors, England & $2-55$ & Trimmer et al. (2000) \\
\hline $\begin{array}{l}\text { Ulva sp., Chaetomorpha sp., } \\
\text { Enteromorpha sp. }\end{array}$ & Virksund \& Ulbjerg, Limfjorden, Denmark & $12-30$ & Dalsgaard (2003) \\
\hline \multirow[t]{6}{*}{ Benthic microalgae } & Kalmar Sound, Baltic Sea & $0.02-6.6$ & Sundbäck et al. (in press) \\
\hline & Danish shallow coastal bays & 4 & Risgaard-Petersen \& Ottosen (2000) \\
\hline & $\begin{array}{l}\text { European estuaries in the UK, Sweden, } \\
\text { Denmark, Italy, and Portugal }\end{array}$ & $\begin{array}{c}0-34 \\
4.2 \text { median }\end{array}$ & Risgaard-Petersen (2003) \\
\hline & Virksund and Ulbjerg, Limfjorden, Denmark & $5-60$ & Dalsgaard (2003) \\
\hline & Hog Island Bay, VA & $1.7-40$ & Anderson et al. (2003) \\
\hline & Galveston Bay, TX & $4-91$ & An \& Joye (2001) \\
\hline \multicolumn{4}{|l|}{$\begin{array}{l}\text { Tropical/subtropical } \\
\text { Seagrass }\end{array}$} \\
\hline Thalassia testudinum & Oyster Bay, Jamaica & 83-167 & Blackburn et al. (1994) \\
\hline Thalassia testudinum & Florida Bay, FL & $67-125$ & Kemp \& Cornwell (2001) \\
\hline
\end{tabular}


iments in tropical/subtropical environments, but rates tend to be somewhat higher than in temperate sediments (Blackburn et al. 1994, Kemp \& Cornwell 2001, Miyajima et al. 2001). More work is needed to determine if denitrification is stimulated in sediments vegetated by tropical seagrasses. These species typically allocate more biomass to roots and rhizomes than temperate species, and are more likely to be P-limited in carbonate sediments so that competition between bacteria and plants for $\mathrm{N}$ is less likely to occur.

Under N-limiting conditions, the activity of benthic microalgae also generally inhibits denitrification rates through competition for $\mathrm{N}$ with bacteria (Rysgaard et al. 1995, An \& Joye 2001). Recent field data from 18 European estuaries showed that net autotrophic sediments colonized by microalgae had lower rates of coupled nitrification-denitrification than net heterotrophic sediments (Risgaard-Petersen 2003). This was also the case for shallow bays in Sweden, where denitrification rates were higher (20\% of remineralized N) in net heterotrophic than in net autotrophic sediments (10\% of remineralized N) (Sundbäck \& Miles 2002). However, when there is sufficient $\mathrm{N}$ to prevent $\mathrm{N}$ limitation, photosynthetic oxygen and DOM release can result in increased rates of coupled nitrificationdenitrification (Lorenzen et al. 1998, An \& Joye 2001, Risgaard-Petersen 2004).

There is relatively little information on the influence of macroalgae on denitrification rates. Trimmer et al. (2000) found that both direct denitrification, using nitrate $\left(\mathrm{NO}_{3}^{-}\right)$supplied from the water column, and denitrification coupled to sedimentary nitrification were low in sediments underlying macroalgal mats. High free sulfide concentrations in organic-rich sediments underlying macroalgal accumulations (Viaroli et al. 1996) may inhibit nitrification (Henriksen \& Kemp 1988, Sloth et al. 1995) and partially account for the low denitrification rates. It appears that the net effect of dense macroalgal mats is to move the zone of denitrification from the sediments up into the oxic-anoxic interface in the mat, but not to influence the rates significantly compared to 'bare' sediments with benthic microalgae (Krause-Jensen et al. 1999, Dalsgaard 2003). Like benthic microalgae, it is expected that macroalgae will compete with bacteria for $\mathrm{NH}_{4}{ }^{+}$and $\mathrm{NO}_{3}{ }^{-}$(Dalsgaard 2003).

Dentrification rates may increase slightly as $\mathrm{N}$ limitation is relaxed, and then would likely decline precipitously as sediments become anoxic and highly sulfidic and DNRA increases. The partitioning between coupled nitrification-denitrification and DNRA depends on oxygen, DOC and sulfide concentrations in the sediment. As sediments become anoxic and sulfidic in the later stages of eutrophication due to high rates of plant decomposition, partitioning of $\mathrm{NO}_{3}^{-}$ reduction is likely to shift from coupled nitrificationdenitrification to DNRA, resulting in less $\mathrm{N}$ removal from the system. This will create a positive feedback, as the $\mathrm{NH}_{4}{ }^{+}$concentration in the sediment and the efflux of $\mathrm{NH}_{4}{ }^{+}$from the sediments to the water column will both increase (Joye \& Hollibaugh 1995, An \& Gardner 2002, Senga et al. 2006), stimulating phytoplankton production, at least in temperate systems. On the other hand, anammox, a process whereby $\mathrm{NO}_{3}{ }^{-}$ serves as an electron acceptor for $\mathrm{NH}_{4}^{+}$oxidation, results in loss of fixed $\mathrm{N}$ as $\mathrm{N}_{2}$. Recent results suggest that anammox bacteria are widely distributed throughout a variety of marine sediments; however, their importance in shallow coastal bays and their regulation by sulfide is currently unknown (Strous et al. 1999, Penton et al. 2006).

Few studies have addressed the degree to which $\mathrm{N}$ fixation compensates for losses of $\mathrm{N}$ via denitrification in shallow coastal bays and how this changes during eutrophication. In low-nutrient systems, $\mathrm{N}$ fixation may more than compensate for $\mathrm{N}$ loss by denitrification (seagrasses; Risgaard-Petersen et al. 1998), and is important in supporting high rates of primary production particularly in tropical/subtropical systems (McGlathery et al. 1998, Risgaard-Petersen et al. 1998, Hanson et al. 2000, Welsh 2000). As eutrophication proceeds, $\mathrm{N}$ fixation would be expected to decline due to the greater availability of DIN as an alternate source (e.g. Yoch \& Whiting 1986, Howarth et al. 1988).

Phosphorus sorption/desorption in sediments. The effects of eutrophication on P cycling is particularly important in subtropical and tropical bays dominated by carbonate sediments where $\mathrm{P}$ is more likely to be limiting to growth. However, we know less about plant-mediated feedbacks on P cycling as eutrophication proceeds in these environments than we do about $\mathrm{N}$ cycling in temperate systems. In oligotrophic habitats, iron oxides that form in the seagrass rhizosphere, effectively bind $\mathrm{P}$ in the solid phase and decrease the release of P to overlying waters (Chambers et al. 2001, Rozan et al. 2002). While it was previously thought that carbonate sediments were a permanent sink for $\mathrm{P}$ and that mineral $\mathrm{P}$ was not available to plants, recent studies suggest that seagrass metabolism facilitates the dissolution of carbonate minerals in the rhizosphere, releasing bound P (Jensen et al. 1998, Burdige \& Zimmerman 2002). This is due in part to the decrease in $\mathrm{pH}$ resulting from root respiration and/or the stimulation of bacterial respiration by root DOM release (Burdige \& Zimmerman 2002), or to the release of organic acids by seagrass roots (M. Long, K. J. McGlathery, J. C. Zieman \& P. Berg unpubl.). However, the dissolution of these pools is likely too slow to support maximum seagrass growth and the pore-water pools represent only a small portion of the required nutrients (McGlathery 
et al. 2001b). An increase in P loading may initially stimulate seagrass production and result in an increase in carbonate dissolution and release of sedimentbound $\mathrm{P}$, but as eutrophication proceeds and algal blooms shade the seagrasses (e.g. McGlathery 2001, Hauxwell et al. 2001, 2003), seagrass metabolism will decline. In sediments of highly eutrophic systems, sulfate reduction will likely increase and sulfides will compete with phosphate for oxidized iron (Heijs et al. 2000, Chambers et al. 2001); this would likely result in the seagrass meadow switching from being a net sink to a source of P (Perez et al. 2001). The increase in P release to the overlying water would be a positive feedback further stimulating algal production and prolonging the negative effects of shading associated with eutrophication (Heijs et al. 2000, Perez et al. 2001).

\section{CONCLUSION}

Primary producers clearly play an important role in the 'coastal filter' in shallow coastal ecosystems, and their effect on nutrient cycling as biotic structure changes during progressive nutrient enrichment is key to understanding eutrophication responses. These biotic feedbacks are manifested in 2 ways: (1) the fate of nutrients temporarily bound in plant biomass (mineralization, long-term retention, grazing, advection), and (2) the effects of plant metabolism on sediment oxygen, nutrient and DOM concentrations that influence biogeochemical processes and nutrient retention. Although we currently have a good understanding of the physiological basis for the change in ecological structure during eutrophication of coastal bays, we still need more information on the mechanisms driving these biotic feedbacks on nutrient cycling and the links to physical processes that will allow us to build quantitative models to predict the response to, and recovery from, eutrophication in these shallow systems. Some have also suggested that eutrophication could lead to alternate stable states of either an algal-dominated or seagrass-dominated community (Knowlton 2004, Valentine \& Duffy 2006), similar to what has been observed in lakes (van Nes et al. 2002, Scheffer \& Carpenter 2003).

Our synthesis on plant-mediated feedbacks suggests that a shift in ecological structure during eutrophication from large macrophytes with slow turnover rates to ephemeral, bloom-forming algae will result in a decrease in long-term retention of recalcitrant dissolved and particulate matter and an increase in masstransport of plant-bound nutrients from the system. Also, denitrification is not likely to be a significant buffer for $\mathrm{N}$ loading to nutrient enrichment because uptake by benthic primary producers typically outcom- petes bacteria for available $\mathrm{N}$, and as sediments become anoxic during the later stages of eutrophication, partitioning of nitrate reduction will shift to DNRA. Both processes result in less removal of $\mathrm{N}$ from the system. Grazing of bloom-forming algae is likely to buffer the effects of nutrient enrichment only at low to moderate nutrient loading rates. Some of these responses to eutrophication are reversible, although recovery is likely to be a slow process, partly because of continuing internal loading from the sediment that would support algal populations (e.g. Hodgkin \& Birch 1986, Richardson 1996, Pihl et al. 1999). As light availability increases following a reduction in external nutrient loading, benthic primary producers once again become important and can accelerate the recovery process by reoxygenating the sediment, intercepting the sediment-water column nutrient flux, and temporarily retaining nutrients in plant biomass.

Acknowledgements. This work was supported by the National Science Foundation through the Virginia Coast Reserve LTER project (DEB 0080381 and DEB 0621014) and the Biocomplexity Coupled Biogeochemical Cycles program (EAR 0420575), and by the US Department of Agriculture (2001-35101-09873). We are grateful to J. W. Stanhope for compiling the nutrient loading data presented in Table 1, to L. Cole for drafting Fig. 1, and to A. Giblin and R. Marino for input to Figs. 4 and 5.

\section{LITERATURE CITED}

Abal EG, Dennison WC (1996) Seagrass depth range and water quality in southern Moreton Bay, Queensland, Australia. Mar Freshw Res 47:763-771

Admiraal W (1984) The ecology of estuarine sediment-inhabiting diatoms. In: Round FE, Chapman DJ (eds) Progress in phycological research. Biopress, Bristol, p 269-314

Alpine AE, Cloern JE (1992) Trophic interactions and direct physical effects control phytoplankton biomass and production in an estuary. Limnol Oceanogr 37:946-955

An S, Gardner WS (2002) Dissimilatory nitrate reduction to ammonium (DNRA) as a nitrogen link, versus denitrification as a sink in a shallow estuary (Laguna Madre/ Baffin Bay, Texas). Mar Ecol Prog Ser 237:41-50

An S, Joye SB (2001) Enhancement of coupled nitrificationdenitrification by benthic photosynthesis in shallow estuarine sediments. Limnol Oceanogr 46:62-74

Anderson IC, McGlathery KJ, Tyler AC (2003) Microbial mediation of 'reactive' nitrogen transformations in a temperate lagoon. Mar Ecol Prog Ser 246:73-84

Asmus H, Asmus R (1985) The importance of grazing food chain for energy flow and production in three intertidal sand bottom communities of the northern Wadden Sea. Helgol Meeresunters 39:273-301

Astill H, Lavery P (2001) The dynamics of unattached benthic macroalgal accumulations in the Swan-Canning Estuary. Hydrol Process 15:2387-2399

Banta GT, Pedersen MF, Nielsen SL (2004) Decomposition of marine primary producers: consequences for nutrient recycling and retention in coastal ecosystems. In: Nielsen SL, Banta GT, Pedersen MF (eds) Estuarine nutrient cycling: 
the influence of primary producers. Kluwer Academic, Dordrecht, p 187-216

Bartoli M, Cattadori M, Giordiani G, Viaroli P (1996) Benthic oxygen respiration, ammonium and phosphorus regeneration in surficial sediments of the Sacca di Goro (Northern Italy) and two French coastal lagoons: a comparative study. Hydrobiologia 329:143-159

Benoy GA, Kalff J (1999) Sediment accumulation and Pb burdens in submerged macrophyte beds. Limnol Oceanogr 44:1081-1090

Blaabjerg VK, Mouritsen KM, Finster K (1998) Diel cycles of sulphate reduction rates in sediments of a Zostera marina bed (Denmark). Aquat Microb Ecol 15:97-102

Blackburn TH, Nedwell DB, Wiebe WJ (1994) Active mineral cycling in a Jamaican seagrass sediment. Mar Ecol Prog Ser 110:233-239

Borum J (1996) Shallow waters and land/sea boundaries. In: Jørgensen BB, Richardson K (eds) Eutrophication in coastal marine ecosystems. Coastal and estuarine studies, Vol 52. American Geophysical Union, Washington, DC, p 179-204

Borum J, Sand-Jensen K (1996) Is total primary production in shallow coastal marine waters stimulated by nitrogen loading? Oikos 76:406-410

Boschker HTS, Wielemaker A, Schaub BEM, Holmer M (2000) Limited coupling of macrophyte production and bacterial carbon cycling in the sediments of Zostera spp. meadows. Mar Ecol Prog Ser 203:181-189

Boynton WR, Garber JH, Summers R, Kemp WM (1995) Inputs, transformations, and transport of nitrogen and phosphorus in Chesapeake Bay and selected tributaries. Estuaries 18:285-314

Boynton WR, Hagy JD, Murray L, Stokes C, Kemp WM (1996) A comparative analysis of eutrophication patterns in a temperate coastal lagoon. Estuaries 19:408-421

Brock DA (2001) Nitrogen budget for low and high freshwater inflows, Nueces Estuary, Texas. Estuaries 24:509-521

Brush MJ, Nixon SW (2002) Direct measurements of light attenuation by epiphytes on eelgrass Zostera marina. Mar Ecol Prog Ser 238:73-79

Buchsbaum R, Valiela I, Swain T, Dzierzeski M, Allen S (1991) Available and refractory nitrogen in detritus of coastal vascular plants and macroalgae. Mar Ecol Prog Ser 72: 131-143

Burdige DJ, Zimmerman RC (2002) Impact of seagrass density on carbonate dissolution in Bahamian sediments. Limnol Oceanogr 47:1761-1763

Buzzelli CP, Christian RR (2001) A preliminary LOICZ budget for the Neuse River Estuary, North Carolina. 16th Biennial Conference of the Estuarine Research Federation, St. Pete Beach, FL, 4-8 November 2001. Available at: http://nest.su.se/MNODE/North\%20America/NeuseRiver/ NeuseRiverbud.htm

Caffrey JM, Kemp WM (1992) Influence of the submersed plant Potamogeton perfuliatus, on nitrogen cycling in estuarine sediments. Limnol Oceanogr 37:1483-1495

Carmichael RH, Annett B, Valiela I (2004) Nitrogen loading to Pleasant Bay, Cape Cod: application of models and stable isotopes to detect incipient nutrient enrichment of estuaries. Mar Poll Bull 48:137-143

Cebrián J (1999) Patterns in the fate of production in plant communities. Am Nat 154:449-468

Cebrián J (2002) Variability and control of carbon consumption, export and accumulation in marine communities. Limnol Oceanogr 47:11-22

Cebrián J (2004) Grazing on benthic primary producers. In: Nielsen SL, Banta GT, Pedersen MF (eds) Estuarine nutri- ent cycling: the influence of primary producers. Kluwer Academic, Dordrecht, p 154-186

Cerco CF (1995) Simulation of long-term trends in Chesapeake Bay eutrophication. J Env Eng 121:298-310

Cerco CF, Seitzinger SP (1997) Measured and modeled effects of benthic algae on eutrophication in Indian RiverRehoboth Bay, Delaware. Estuaries 20:231-248

Chambers RM, Fourqurean JW, Macko SA, Hoppenot R (2001) Biogeochemical effects of iron availability on primary producers in a shallow marine carbonate environment. Limnol Oceanogr 46:1278-1286

Chambers RM, Osgood DT, Bart DJ, Montalto F (2003) Phragmites australis invasion and expansion in tidal wetlands: interactions among salinity, sulfide and hydrology. Estuaries 26:398-406

Cloern JE (2001) Our evolving conceptual model of the coastal eutrophication problem. Mar Ecol Prog Ser 210:223-253

Cohen JE, Small C, Mellinger A, Gallup J, Sachs JD (1997) Estimates of coastal populations. Science 278:1211

Cooper SR, Brush GS (1993) Historical trends in contamination of estuarine and coastal sediments. Estuaries 16:617-626

Cornwell JC, Kemp WM, Kana TM (1999) Denitrification in coastal ecosystems: environmental controls and aspects of spatial and temporal scaling. J Aquat Ecol 33:41-54

Costanza R, d'Arge R, deGroot R, Farber S and 9 others (1997) The value of the world's ecosystem services and natural capital. Nature 387: 253-260

Dalsgaard T (2003) Benthic primary production and nutrient cycling in sediments with benthic microalgae and transient accumulation of macroalgae. Limnol Oceanogr 48: 2138-2150

de Brouwer JFC, Bjelic S, de Deckere EM, Stal LJ (2000) Interplay between biology and sedimentology in a mudflat (Biezelingse Ham, Westerschelde, The Netherlands). Cont Shelf Res 20:1159-1177

Deegan LA (1993) Nutrient and energy transport between estuaries and coastal marine ecosystems by fish migration. Can J Fish Aquat Sci 50:74-79

de Jonge VN, van Beusekom JEE (1996) Wind- and tideinduced resuspension of sediment and microphytobenthos from tidal flats in the Ems Estuary. Limnol Oceanogr 40: $766-778$

de Wit R, Stal LJ, Lomstein BA, Herbert RA and 18 others (2001) ROBUST: the ROle of BUffering capacities in STabilizing coastal lagoon ecosystems. Cont Shelf Res 21: 2001-2041

Diaz RJ, Rosenberg R (1995) Marine benthic hypoxia: a review of its ecological effects and the behavioral responses of benthic macrofauna. Oceanogr Mar Biol Annu Rev 33:245-303

Duarte CM (1995) Submerged aquatic vegetation in relation to different nutrient regimes. Ophelia 41:87-112

Duarte CM, Cebrián J (1996) The fate of marine autotrophic production. Limnol Oceanogr 41:1758-1766

Duffy JE, Harvilicz AM (2001) Species-specific impacts of grazing amphipods in an eelgrass-bed community. Mar Ecol Prog Ser 223:201-211

Duffy JE, Richardson JP, Canuel EA (2003) Grazer diversity effects on ecosystem functioning in seagrass beds. Ecol Lett 6:637-645

Enriquez S, Duarte CM, Sand-Jensen K (1993) Patterns in decomposition rates among photosynthetic organisms: the importance of detritus C:N:P content. Oecologia 94: $457-471$

EPA (Environmental Protection Agency) (2001) National coastal condition report. EPA-620/R01/005, Office of Research and Development and Office of Water, US EPA, Washington, DC 
Eyre BD, Ferguson AJP (2002) Comparison of carbon production and decomposition, benthic nutrient fluxes and denitrification in seagrass, phytoplankton, benthic microalgaeand macroalgae-dominated warm-temperate Australian lagoons. Mar Ecol Prog Ser 229:43-59

Flindt MR (1994) Measurements of nutrient fluxes and mass balances by on-line in situ dialysis in a Zostera marina bed culture. Int Limnol Theor Appl 25:2259-2264

Flindt MR, Neto J, Amos CL, Pardal MA, Bergamasco A, Pedersen CB, Andersen FØ (2004) Plant bound nutrient transport: Mass transport in estuaries and lagoons. In: Nielsen SL, Banta GT, Pedersen MF (eds) Estuarine nutrient cycling: the influence of primary producers. Kluwer Academic, Dordrecht, p 93-128

Fourqurean JW, Powell GVN, Kenworthy WJ, Zieman JC (1995) The effects of long-term manipulation of nutrient supply on competition between the seagrasses Thalassia testudinum and Halodule wrightii in Florida Bay. Oikos 72:349-358

Frederiksen, MS, Glud RN (2006) Oxygen dynamics in the rhizosphere of Zostera marina: a two-dimensional planar optode study. Limnol Oceanogr 51:1072-1083

Gacia E, Duarte CM, Middelburg JJ (2002) Carbon and nutrient deposition in a Mediterranean seagrass (Posidonia oceanica) meadow. Limnol Oceanogr 47:23-32

Gargas M, Gargas E (1982) Influence of temperature and oxygen conditions on microphytobenthos stored for longer periods in darkness. Vatten 38:306-316

Giblin AE, Gaines AG (1990) Nitrogen inputs to a marine embayment: the importance of groundwater. Biogeochemistry 10:309-328

Glud RN, Kühl M, Kohls O, Ramsing NB (1999) Heterogeneity of oxygen production in a photosynthetic microbial mat studied by planar optodes. J Phycol 35:270-279

Goecker ME, Heck KL Jr, Valentine JF (2005) Effects of nitrogen concentrations in turtle grass Thalassia testudinum on consumption by the bucktooth parrotfish Sparisoma radians. Mar Ecol Prog Ser 286:239-248

Goodman JL, Moore KA, Dennison WC (1995) Photosynthetic responses of eelgrass (Zostera marina L.) to light and sediment sulfide in a shallow barrier island lagoon. Aquat Bot 50:37-47

Goto N, Kawamura T, Mitamura O, Terai H (1999) Importance of extracellular organic carbon production in the total primary production by tidal-flat diatoms in comparison to phytoplankton. Mar Ecol Prog Ser 190:289-295

Grall J, Chauvaud L (2002) Marine eutrophication and benthos: the need for new approaches and concepts. Global Change Biol 8:813-830

Greve TM, Borum J, Pedersen O (2003) Meristematic oxygen variability in eelgrass (Zostera marina). Limnol Oceanogr 48:210-216

Haamer J (1996) Improving water quality in a eutrophied fjord system with mussel farming. Ambio 25:356-362

Haamer J, Rohde J (2000) Mussel Mytilus edulis (L.) filtering of the Baltic Sea outflow through the Oresund-an example of a natural, large-scale ecosystem restoration. J Shellfish Res 19:413-421

Hagy JD, Boynton WR, Keefe CW, Wood KV (2004) Hypoxia in Chesapeake Bay, 1950-2001: long-term change in relation to nutrient loading and river flow. Estuaries 27: 634-658

Hansen JW, Udy JW, Perry CL, Dennison WC, Lomstein BAa (2000) Effect of the seagrass Zostera capricorni on sediment microbial processes. Mar Ecol Prog Ser 199:83-96

Hauxwell J, McClelland J, Behr PJ, Valiela I (1998) Relative importance of grazing and nutrient controls of macroalgal biomass in three temperate shallow estuaries. Estuaries 21:347-360

Hauxwell J, Cebrián J, Furlong C, Valiela I (2001) Macroalgal canopies contribute to eelgrass (Zostera marina) decline in temperate estuarine ecosystems. Ecology 82:1007-1022

Hauxwell J, Cebrián J, Valiela I (2003) Eelgrass Zostera marina loss in temperate estuaries: relationship to landderived nitrogen loads and effect of light limitation imposed by algae. Mar Ecol Prog Ser 247:59-73

Havens KE, Hauxwell J, Tyler AC, Thomas S and 5 others (2001) Complex interactions between autotrophs in shallow marine and freshwater ecosystems: implications for community responses to nutrient stress. Environ Poll 113:95-107

Heck KL Jr, Valentine JF (2007) The primacy of top-down effects in shallow benthic systems. Estuar Coasts 30: 371-381

Heck KL Jr, Pennock JR, Valentine JF, Cohen LD, Sklenar SA (2000) Effects of nutrient enrichment and small predator density on seagrass ecosystems: an experimental assessment. Limnol Oceanogr 45:1041-1057

Heijs SK, Azzoni R, Giordani G, Jonkers HM, Nizzoli D, Viaroli $P$, van Gemerden H (2000) Sulfide-induced release of phosphate from sediments of coastal lagoons and the possible relation to the disappearance of Ruppia sp. Aquat Microb Ecol 23:85-85

Henriksen K, Kemp WM (1988) Nitrification in estuarine and coastal marine sediments. In: Blackburn TH, Sørensen J (eds) Nitrogen cycling in coastal marine environments, SCOPE. John Wiley \& Sons, Chichester, p 201-255

Herman PMJ, Middelburg JJ, Widdows MJ, Lucas CH, Heip CHR (2000) Stable isotopes as trophic tracers: combining field sampling and manipulative labeling of food resources for macrobenthos. Mar Ecol Prog Ser 204:79-92

Hillebrand H, Kahlert M (2002) Effect of grazing and water column nutrient supply on biomass and nutrient content of sediment microalgae. Aquat Bot 72:143-159

Hillebrand HB, Worm B, Lotze HK (2000) Marine microbenthic community structure regulated by nitrogen loading and grazing pressure. Mar Ecol Prog Ser 204:27-38

Hodgkin EP, Birch PB (1986) No simple solution: proposing radical management options for a eutrophic estuary. Mar Poll Bull 17:399-404

Holmer M, Bondgaard EJ (2001) Photosynthesis and growth response of eelgrass to low oxygen and high sulfide concentrations during hypoxic events. Aquat Bot 70:29-38

Horn MH (1989) Biology of marine herbivorous fishes. Oceanogr Mar Biol Ann Rev 27:167-272

Howard RK, Short FT (1986) Seagrass growth and survivorship under the influence of epiphyte grazers. Aquat Bot 24: 287-302

Howarth RW, Marino R, Lane J, Cole JJ (1988) Nitrogen fixation in freshwater, estuarine, and marine ecosystems. 1. Rates and importance. Limnol Oceanogr 33:669-687

Howarth RW, Anderson D, Cloern J, Elfring C and 7 others (2000) Nutrient pollution of coastal rivers, bays and seas. Issues in Ecology No. 7. Ecological Society of America, Washington, DC

Howarth RW, Boyer EW, Pabich WJ, Galloway JN (2002) Nitrogen use in the United States from 1961-2000 and potential future trends. Ambio 31:88-96

Janicki A, Pribble R, Zarbock H, Janicki S, Winowitch M (2001) Model-based estimates of total nitrogen loading to Tampa Bay: current conditions and updated 2010 conditions. Report prepared for Tampa Bay Estuary Program, St. Petersburg, FL, p 83

Jensen HS, McGlathery KJ, Marino R, Howarth RW (1998) Forms and availability of sediment phosphorus in carbon- 
ate sand of Bermuda seagrass beds. Limnol Oceanogr 43:799-810

Joye SB, Hollibaugh JT (1995) Influence of sulfide inhibition of nitrification on nitrogen regeneration in sediments. Science 270:623-625

Kautsky N, Kautsky H, Kautsky I, Waern M (1986) Decreased depth penetration of Fucus vesiculosus (L.) since the 1940's indicates eutrophication of the Baltic Sea. Mar Ecol Prog Ser 28:1-8

Kemp WM, Cornwell JC (2001) Role of benthic communities in the cycling and balance of nitrogen in Florida Bay. Final report to the US Environmental Protection Agency, Region 4, Atlanta, GA, p 53

Kennett DM, Hargraves PE (1985) Benthic diatoms and sulfide fluctuations: upper basin of Pettaquamscutt River, Rhode Island. Estuar Coast Shelf Sci 21:577-586

Kenworthy WJ, Zieman JC, Thayer GW (1982) Evidence for the influence of seagrasses on the benthic nitrogen cycle in a coastal plain estuary near Beaufort, North Carolina (USA). Oecologia 54:152-158

Knowlton N (2004) Multiple 'stable' states and the conservation of marine ecosystems. Prog Oceanogr 60:387-396

Koepfler ET, Benner R, Montagna PA (1993) Variability of dissolved organic carbon in sediments of a seagrass bed and an unvegetated area within an estuary in southern Texas. Estuaries 16:391-404

Krause-Jensen D, McGlathery K, Rysgaard S, Christensen PB (1996) Production within dense mats of the filamentous macroalga Chaetomorpha linum in relation to light and nutrient availability. Mar Ecol Prog Ser 134:207-216

Krause-Jensen D, Christensen PB, Rysgaard S (1999) Oxygen and nutrient dynamics within mats of the filamentous macroalga Chaeotomorpha linum. Estuaries 22:31-38

Kristensen E (2000) Organic matter diagenesis at the oxic/ anoxic interface in coastal marine sediments, with emphasis on the role of burrowing animals. Hydrobiologia 426:1-24

Kristensen E, Ahmed SI, Devol AH (1995) Aerobic and anaerobic decomposition of organic matter in marine sediment: which is fastest? Limnol Oceanogr 40:1430-1437

Kuipers BR, de Wilde PAWJ, Creutzberg F (1981) Energy flow in a tidal flat ecosystem. Mar Ecol Prog Ser 5:215-221

Lawson SE, Wiberg PL, McGlathery KJ, Fugate DC (2007) Wind-driven sediment suspension controls light availability in a shallow coastal lagoon. Estuar Coasts 30:102-111

Lee V, Olsen S (1985) Eutrophication and management initiatives for the control of nutrient inputs to Rhode Island coastal lagoons. Estuaries 8:191-202

Lin HJ, Nixon SW, Taylor DI, Granger SL, Buckley BA (1996) Responses of epiphytes on eelgrass, Zostera marina L., to separate and combined nitrogen and phosphorus enrichment. Aquat Bot 52:243-258

Lorenzen J, Larsen LH, Kjaer T, Revsbech NP (1998) Biosensor determination of the microscale distribution of nitrate, nitrate assimilation, nitrification, and denitrification in a diatom-inhabited freshwater sediment. Appl Environ Microbiol 64:3264-3269

Lotze HK, Worm B (2002) Complex interactions of climatic and ecological controls on macroalgal recruitment. Limnol Oceanogr 47:1734-1741

Madsen KN, Nilsson N, Sundbäck K (1993) The influence of benthic microalgae on the stability of a subtidal sediment. J Exp Mar Biol Ecol 170:159-177

McGlathery KJ (1995) Nutrient and grazing influences on a subtropical seagrass community. Mar Ecol Prog Ser 122:239-252

McGlathery (2001) Macroalgal blooms contribute to the decline of seagrass in nutrient-enriched coastal waters. J Phycol 37:1-4
McGlathery KJ, Krause-Jensen D, Rysgaard S, Christensen PB (1997) Patterns of ammonium uptake within dense mats of the filamentous macroalga Chaetomorpha linum. Aquat Bot 59:99-115

McGlathery KJ, Risgaard-Petersen N, Christensen PB (1998) Temporal and spatial variation in nitrogen fixation activity in the eelgrass Zostera marina rhizosphere. Mar Ecol Prog Ser 168:245-258

McGlathery KJ, Anderson IC, Tyler AC (2001a) Magnitude and variability of benthic and pelagic metabolism in a temperate coastal lagoon. Mar Ecol Prog Ser 216:1-15

McGlathery, KJ, Berg P, Marino R (2001b) Using porewater profiles to assess nutrient availability in seagrass-vegetated carbonate sediments. Biogeochemistry 56:239-263

McGlathery KJ, Sundbäck K, Anderson IC (2004) The importance of primary producers for benthic nitrogen and phosphorus cycling. In: Nielsen SL, Banta GT, Pedersen MF (eds) Estuarine nutrient cycling: the influence of primary producers. Kluwer Academic, Dordrecht, p 231-262

Meyercordt J, Meyer-Reil LA (1999) Primary production of benthic microalgae in two shallow coastal lagoons of different trophic status in the southern Baltic Sea. Mar Ecol Prog Ser 178:179-191

Middelburg JJ, Soetaert K, Herman PHJ, Boschker HTS, Heip CR (2004) Burial of nutrients in coastal sediments: the role of primary producers. In: Nielsen SL, Banta GT, Pedersen MF (eds) Estuarine nutrient cycling: the influence of primary producers, Kluwer Academic, Dordrecht, $p$ $217-230$

Miyajima T, Suzumura M, Umezawa Y, Koike I (2001) Microbial nitrogen transformation in carbonate sediments of a coral-reef lagoon and associated seagrass beds. Mar Ecol Prog Ser 217:273-286

Monbet Y (1992) Control of phytoplankton biomass in estuaries: a comparative analysis of microtidal and macrotidal estuaries. Estuaries 15:563-571

Moriarty DW, Iverson JR, Pollard PC (1986) Exudation of organic carbon by the seagrass Halodule wrightii and its effect on bacterial growth in the sediment. J Exp Biol Ecol 96:115-126

Neckles HA, Wetzel RL, Orth RJ (1993) Relative effects of nutrient enrichment and grazing on epiphyte-macrophyte (Zostera marina) dynamics. Oecologia 93:285-295

Neckles HA, Koepfler ET, Haas LW, Wetzel RL, Orth RJ (1994) Dynamics of epiphytic photoautotrophs and heterotrophs in Zostera marina (eelgrass) microcosms: responses to nutrient enrichment and grazing. Estuaries 17:597-605

Nielsen SL, Sand-Jensen K, Borum J, Geertz-Hansen (2002) Depth colonization of eelgrass (Zostera marina) and macroalgae as determined by water transparency in Danish coastal waters. Estuaries 25:1025-1032

Nielsen SL, Banta GT, Pedersen MF (eds) (2004) Estuarine nutrient cycling: the influence of primary producers, Kluwer Academic, Dordrecht

Nilsson P, Jönsson B, Lindström Swanberg I, Sundbäck K (1991) Response of a marine shallow-water sediment system to an increased load of inorganic nutrients. Mar Ecol Prog Ser 71:275-290

Nixon SW (1997) Prehistoric nutrient inputs and productivity in Narragansett Bay. Estuaries 20:253-261

Nixon SW, Ammerman JW, Atkinson LP, Berounsky WM and 11 others (1996) The fate of nitrogen and phosphorus at the land-sea margin of the North Atlantic Ocean. Biogeochemistry 35:141-180

Nixon SW, Buckley B, Granger S, Bintz J (2001) Responses of very shallow marine ecosystems to nutrient enrichment. Human Ecol Risk Assess 7:1457-1481 
NRC (National Research Council) (2000) Clean coastal waters: understanding and reducing the effects of nutrient pollution. National Academy Press, Washington, DC

Oberg J (2005) Model simulations of conditions suitable for the establishment of Enteromorpha sp. (Chlorophyta) macroalgal mats. Mar Biol Res 1:97-106

Ottosen LDM, Risgaard-Petersen N, Nielsen LP (1999) Direct and indirect measurements of nitrification and denitrification in the rhizosphere of aquatic macrophytes. Aquat Microb Ecol 19:81-91

Paerl HW (1995) Coastal eutrophication in relation to atmospheric nitrogen deposition: current perspectives. Ophelia 41:237-259

Peckol P, Rivers JS (1996) Contribution by macroalgal mats to primary production of a shallow embayment under high and low nitrogen-loading rates. Estuar Coast Shelf Sci 43: 311-325

Pedersen MF, Nielsen SL, Banta GT (2004) Interactions between vegetation and nutrient dynamics in coastal marine ecosystems: an introduction. In: Nielsen SL, Banta GT, Pedersen MF (eds) Estuarine nutrient cycling: the influence of primary producers, Kluwer Academic, Dordrecht, p 1-16

Penton CR, Devol AH, Tiedje JM (2006) Molecular evidence for the broad distribution of anaerobic ammonium-oxidizing bacteria in freshwater and marine sediments. Appl Environ Microbiol 72:6829-6832

Perez M, Mateo MA, Alcoverro T, Romero J (2001) Variability in detritus stocks in beds of the seagrass Cymodocea nodosa. Bot Mar 44:523-531

Pihl L, Svenson A, Moksnes PO, Wennhage H (1999) Distribution of green algal mats throughout shallow soft bottoms of the Swedish Skagerrak archipelago in relation to nutrient sources and wave exposure. J Sea Res 41:281-294

Pinckney JL, Carman KR, Lumsden SE, Hymel SN (2003) Microalgal-meiofaunal trophic relationships in muddy intertidal estuarine sediments. Aquat Microb Ecol 31:99-108

Pregnall AM, Smith RD, Kursar TA, Alberte RS (1984) Metabolic adaptations of Zostera marina (eelgrass) to diurnal periods of root anoxia. Mar Biol 83:141-147

Richardson K (1996) Conclusion, research and eutrophication control. In: Jørgensen BB, Richardson K (eds) Eutrophication in coastal marine ecosystems. Coastal and estuarine studies, Vol 52. American Geophysical Union, Washington, DC, p 243-267

Risgaard-Petersen N (2003) Coupled nitrification-denitrification in autotrophic and heterotrophic estuarine sediments: on the influence of benthic microalgae. Limnol Oceanogr 48:93-105

Risgaard-Petersen N (2004) Denitrification. In: Nielsen SL, Banta GT, Pedersen MF (eds) Estuarine nutrient cycling: the influence of primary producers. Kluwer Academic, Dordrecht, p 263-280

Risgaard-Petersen N, Ottosen LDM (2000) Nitrogen cycling in two temperate Zostera marina beds: seasonal variation. Mar Ecol Prog Ser 198:93-107

Risgaard-Petersen N, Dalsgaard T, Rysgaard S, Christensen PB, Borum J, McGlathery KJ, Nielsen LP (1998) Nitrogen balance of a temperate eelgrass Zostera marina bed. Mar Ecol Prog Ser 174:281-291

Rizzo WM, Lackey GL, Christian RR (1992) Significance of euphotic, subtidal sediments to oxygen and nutrient cycling in a temperate estuary. Mar Ecol Prog Ser 86:51-61

Rizzo WM, Dailey SK, Lackey GJ, Christian RR, Berry BB, Wetzel RL (1996) A metabolism-based trophic index for comparing the ecological values of shallow-water sediment habitats. Estuaries 19:247-256
Rosinski JL (2004) Controls on benthic biodiversity and trophic interactions in a coastal lagoon. $\mathrm{PhD}$ dissertation, University of Virginia, Charlottesville, VA

Rozan TF, Taillefert M, Trouwborst RE, Glazer BT and 5 others (2002) Iron-sulfur-phosphorus cycling in the sediments of a shallow coastal bay: Implications for sediment nutrient release and benthic macroalgal blooms. Limnol Oceanogr 47:1346-1354

Rysgaard S, Christensen PB, Nielsen LP (1995) Seasonal variation in nitrification and denitrification in estuarine sediment colonized by benthic microalgae and bioturbating infauna. Mar Ecol Prog Ser 126:111-121

Rysgaard S, Risgaard-Petersen N, Sloth NP (1996) Nitrification, denitrification, and nitrate ammonification in sediments of two coastal lagoons in Southern France. Hydrobiologia 329:133-141

Sand-Jensen K (1977) Effects of epiphytes on eelgrass photosynthesis. Aquat Bot 3:55-63

Sand-Jensen K, Borum J (1991) Interactions among phytoplankton, periphyton, and macrophytes in temperate freshwaters and estuaries. Aquat Bot 41:137-175

Scavia D, Justic D, Bierman VJ (2004) Reducing hypoxia in the Gulf of Mexico: advice from three models. Estuaries 27:419-425

Scavia D, Kelly ELA, Hagy JD (2006) A simple model for forecasting the effects of nitrogen loads on Chesapeake Bay hypoxia. Estuar Coasts 29:674-684

Scheffer M, Carpenter SR (2003) Catastrophic regime shifts in ecosystems: linking theory to observation. Trends Ecol Evol 18:648-656

Schories D, Reise K (1993) Germination and anchorage of Enteromorpha spp. in the sediment of the Wadden Sea. Helgol Meeresunters 47:275-285

Seitzinger SP (2000) Scaling up: site-specific measurements to global-scale estimates of denitrification. In: Hobbie JE (ed) Estuarine science: a synthetic approach to research and practice. Island Press, Washington, DC, p 211-240

Senga Y, Mochida K, Ryouko F, Okamoto N, Seike Y (2006) $\mathrm{N}_{2} \mathrm{O}$ accumulation in estuarine and coastal sediments: The influence of $\mathrm{H}_{2} \mathrm{~S}$ on dissimilatory nitrate reduction. Estuar Coast Shelf Sci 67:231-238

Sfriso A, Pavoni B, Marcomini A, Orio AA (1992) Macroalgae, nutrient cycles, and pollutants in the lagoon of Venice. Estuaries 15:517-528

Short FT, Wyllie-Escheverria S (1996) Natural and human-induced disturbance of seagrasses. Environ Conserv 23:17-27

Short FT, Burdick DM, Kaldy JE III (1995) Mesocosm experiments quantify the effects of eutrophication on eelgrass, Zostera marina. Limnol Oceanogr 40:740-749

Sigua GC, Tweedale WA (2003) Watershed scale assessment of nitrogen and phosphorus loadings in the Indian River Lagoon basin, Florida. J Environ Manag 67:363-372

Sloth NP, Blackburn H, Hansen LS, Risgaard-Petersen N, Lomstein BAa (1995) Nitrogen cycling in sediments with different organic loading. Mar Ecol Prog Ser 116:163-170

Stanhope JW (2003) Relationships between watershed characteristics and base flow nutrient discharges to Eastern Shore coastal lagoons, Virginia. MS thesis, College of William and Mary, Gloucester Point, VA

Strous M, Fuerst JA, Kramer EHM, Logeman S and 5 others (1999) Missing lithotroph identified as new planktomycete. Nature 400:446-449

Sundbäck K, Granéli W (1988) Influence of microphytobenthos on the nutrient flux between sediment and water: a laboratory study. Mar Ecol Prog Ser 43:63-69

Sundbäck K, McGlathery KJ (2005) Interaction between benthic macro- and microalgae in the marine environment. 
In: Kristensen EJ, Kostka E, Haese RH (eds) Interactions between macro- and microorganisms in marine sediments. American Geophysical Union, Washington, DC

Sundbäck K, Miles A (2002) Role of microphytobenthos and denitrification for nutrient turnover in embayments with floating macroalgal mats: a spring situation. Aquat Microb Ecol 30:91-101

Sundbäck K, Jönsson B, Nilsson P, Lindström I (1990) Impact of accumulating drifting macroalgae on a shallow-water sediment system: an experimental study. Mar Ecol Prog Ser 58:261-274

Sundbäck K, Enoksson V, Granéli W, Pettersson K (1991) Influence of sublittoral microphytobenthos on the oxygen and nutrient flux between sediment and water: a laboratory continuous-flow study. Mar Ecol Prog Ser 74:263-279

Sundbäck K, Carlson L, Nilsson C, Jönsson B, Wulff A, Odmark S (1996) Response of benthic microbial mats to drifting green algal mats. Aquat Microb Ecol 10:195-208

Sundbäck K, Miles A, Linares F (2006) Nitrogen dynamics in non-tidal littoral sediments: role of microphytobenthos and denitrification. Estuar Coasts 30:371-381

Swaney D, Scavia D, Howarth RW, Marino R (in press) Estuarine classification and response to nutrient loading: Insights from simple ecological models. Estuar Coast Shelf Sci

Taylor D, Nixon S, Granger S, Buckley B (1995) Nutrient limitation and the eutrophication of coastal lagoons. Mar Ecol Prog Ser 127:235-244

Terrados J, Duarte CM, Kamp-Nielsen L, Agawin NSR and 6 others (1999) Are seagrass growth and survival constrained by reducing conditions of the sediment? Aquat Bot 65:175-107

Thomsen MS (2004) Species, thallus size and substrate determine macroalgal break forces and break places in a low energy soft bottom lagoon. Aquat Bot 80:153-161

Thomsen M, McGlathery KJ (2005) Facilitation of macroalgae by the sedimentary tube-forming polychaete Diopatra cuprea. Estuar Coast Shelf Sci 62:63-73

Thornton DCO, Underwood GJC, Nedwell DB (1999) Effect of illumination and emersion period on the exchange of ammonium across the estuarine sediment-water interface. Mar Ecol Prog Ser 184:11-20

Tomasko DA, Bristol DL, Ott JA (2001) Assessment of present and future nitrogen loads, water quality, and seagrass (Thalassia testudinum) depth distribution in Lemon Bay, Florida. Estuaries 24:926-938

Trimmer M, Nedwell DB, Sivyer DB, Malcolm SJ (2000) Seasonal benthic organic matter mineralisation measured by oxygen uptake and denitrification along a transect of the inner and outer River Thames estuary, UK. Mar Ecol Prog Ser 197:103-119

Twilley RR, Kemp WM, Staver KW, Stevenson JC, Boynton WR (1985) Nutrient enrichment of estuarine submersed vascular plant communities. 1. Algal growth and effects on production of plants and associated communities. Mar Ecol Prog Ser 23:179-191

Tyler AC, McGlathery KJ, Anderson IC (2001) Macroalgal mediation of dissolved organic nitrogen fluxes in a temperate coastal lagoon. Estuar Coast Shelf Sci 53:155-168

Tyler AC, McGlathery KJ, Anderson IC (2003) Benthic algae control sediment-water column fluxes of nitrogen in a temperate lagoon. Limnol Oceanogr 48:2125-2137

Udy JW, Dennison WC (1997) Growth and physiological responses of the three seagrass species to elevated sediment nutrients in Moreton Bay, Australia. J Exp Mar Biol Ecol 217:253-277

Udy JW, Dennison WC, Lee Long WJ, McKenzie LJ (1999) Responses of seagrass to nutrients in the Great Barrier Reef, Australia. Mar Ecol Prog Ser 185:257-271
Underwood GJC, Paterson DM (1993) Seasonal changes in diatom biomass, sediment stability and biogenic stabilization in the Severn Estuary. J Mar Biol Assoc UK 73: 871-887

Valentine JF, Duffy JE (2006) The central role of grazing in seagrass ecology. In: Larkum WD, Orth RJ, Duarte CM (eds) Seagrasses: biology, ecology, and conservation. Springer, Dordrecht, $\mathrm{p}$ 463-501

Valentine JF, Heck KL Jr (2001) The role of leaf nitrogen content in determining turtlegrass (Thalassia testudinum) grazing by a generalist herbivore in the northeastern Gulf of Mexico. J Exp Mar Biol Ecol 258:65-86

Valiela I, Foreman K, LaMontagne M, Hersh D and 8 others (1992) Couplings of watersheds and coastal waters: sources and consequences of nutrient enrichment in Waquoit Bay, Massachusetts. Estuaries 15:443-457

Valiela I, McClelland J, Hauxwell J, Behr PJ, Hersh D, Foreman K (1997) Macroalgal blooms in shallow estuaries: Controls and ecophysiological and ecosystem consequences. Limnol Oceanogr 42:1105-1118

Valiela I, Geist M, McClelland J, Tomasky G (2000) Nitrogen loading from watersheds to estuaries: verification of Waquoit Bay Nitrogen Loading Model. Biogeochemistry 49:277-293

van Nes EJ, Scheffer M, van den Berg MS, Coops H (2002) Dominance of charophytes in eutrophic shallow lakeswhen should we expect it to be an alternative stable state? Aquat Bot 72:275-296

Veuger B, van Oevelen D, Boschker TS, Middelburg JJ (2006) Fate of peptidoglycan in an intertidal sediment: an in situ ${ }^{13} \mathrm{C}$-labeling study. Limnol Oceanogr 51: 1572-1580

Viaroli P, Bartoli M, Bondavalli C, Christian RR (1996) Macrophyte communities and their impact on benthic fluxes of oxygen, sulphide and nutrients in shallow eutrophic environments. Hydrobiologia. 329:105-119

Welsh DT (2000) Nitrogen fixation in seagrass meadows: Regulation, plant-bacteria interactions and significance to primary productivity. Ecol Letters 3:58-71

Welsh DT, Bourgues S, de Wit R, Herbert RA (1996) Seasonal variations in nitrogen-fixation (acetylene reduction) and sulphate-reduction rates in the rhizosphere of Zostera noltii: nitrogen fixation by sulfate-reducing bacteria. Mar Biol 125:619-628

Welsh DT, Bartoli M, Nizzoli D, Castaldelli G, Riou SA, Viaroli P (2000) Denitrification, nitrogen fixation, community primary productivity and inorganic-N and oxygen fluxes in an intertidal Zostera noltii meadow. Mar Ecol Prog Ser 208:65-77

Williams SL, Ruckelshaus MH (1993) Effects of nitrogen availability and herbivory on eelgrass (Zostera marina) and epiphytes. Ecology 74:904-918

Wolfstein K, de Brouwer JFC, Stal LJ (2002) Biochemical partitioning of photosynthetically fixed carbon by benthic diatoms during short-term incubations at different irradiances. Mar Ecol Prog Ser 245:21-31

Worm B, Lotze HK, Sommer U (2000) Coastal food web structure, carbon storage and nitrogen retention regulated by consumer pressure and nitrogen loading. Limnol Oceanogr 45:339-349

Yoch DC, Whiting GJ (1986) Evidence for $\mathrm{NH}_{4}{ }^{+}$switch-off regulation of nitrogenase activity by bacteria in salt marsh sediment and roots of the grass Spartina alterniflora. Appl Environ Microbiol 51:143-149

Ziegler S, Benner R (1999) Nutrient cycling in the water column of a subtropical seagrass meadow. Mar Ecol Prog Ser 188:51-62 